\title{
An international integration history of the Zagreb Stock Exchange
}

\author{
LUKA ŠIKIĆ, mag. oec.* \\ MISLAV ŠAGOVAC, mag. oec.*
}

Article**

JEL: G10, G15, N24

https://doi.org.10.3326/pse.41.2.4

\footnotetext{
${ }^{* *}$ Received: December 21, 2016

Accepted: March 14, 2017

\section{Luka ŠIKIĆ}

Ivo Pilar Institute of Social Sciences, Marulićev trg 19/I, 10000 Zagreb, Croatia e-mail: luka.sikic@pilar.hr

ORCID iD: 0000-0003-0971-9030

Mislav ŠAGOVAC

Contentio d.o.o., S. Tomaševića 7, 10410 Velika Gorica, Croatia

e-mail: mislavsagovac@yahoo.com

ORCID iD: 0000-0001-9486-6726
}

* The authors would like to thank to the two anonymous referees for useful comments and suggestions. 


\begin{abstract}
We investigate stock market co-movements among the Croatian and several other markets (in the US, UK, Germany, Austria, Poland, Czech Republic and Hungary) in the period from 3 September 1997 to 19 August 2016 with dynamic correlation coefficient models. This allows us to analyse long-term trends of the international financial integration of the Zagreb Stock Exchange in the last two decades as well as the separate impacts of major events that influenced financial markets during that period. Our results imply a relatively low level of international financial integration of the Croatian stock market, but some convergence in co-movement with the analysed markets over time is present. The strongest market co-movement is related to the subprime mortgage crisis, and EU accession seems to have made Croatian international integration less segmented.
\end{abstract}

Keywords: stock market co-movement, Croatian international financial integration, dynamic correlation coefficient models

\title{
1 INTRODUCTION
}

The emerging European stock markets have brief histories compared to more mature markets. Most emerging European countries actively follow economic policies that lead towards more internationally integrated financial markets, yet full integration of these countries' financial markets is far from complete. Since their initial trading sessions in the first half of the 1990s, the emerging European stock markets have had varied performances in terms of international integration. Horvat and Petrovski (2013) find that Central European stock markets are highly integrated into the global financial system, whereas those of South-Eastern Europe exhibit a much lower degree of integration. Due to the special characteristics of the Croatian transition process relative to other emerging EU countries (i.e. war destruction in the initial transition phase, delayed EU accession), its financial integration needs to be investigated individually.

In this paper, we examine the co-movement of the Croatian stock market with various European and global financial markets. We are interested in the long-term perspective of financial integration but investigate the impact of several major financial events in last two decades on the integration process as well. There has been some research on stock market integration and closely related topics for emerging European countries (Cappiello et al., 2006; Egert and Kocenda, 2007; Horvat and Petrovski, 2013; Ivanov, 2014), but a detailed examination of the Croatian stock market is lacking. Therefore, we collect daily data on the closing prices of stock market indices from the Zagreb Stock Exchange and several European (UK - FTSE100, broad EU - STOXX600, German - DAX, Austrian - ATX, Polish - WIG20, Czech - PX and Hungarian - BUX) and global (US - S\&P500) markets for the period of 3 September 1997 to 19 August 2016. We identified several important events from the literature on the stock market integration of emerging European countries: the Russian crisis (see Jochum et al., 1999; Gelos and Sahay, 2000), the dot-com crisis and the 9/11 shocks, the subprime mortgage 
crisis (see Gijka and Horvath, 2012), and EU accession (see Cappiello et al., 2006b). Next to these events, we analyse the full sample period as well.

The first significant financial shocks for emerging European markets were the Asian and Russian crisis but since it is hard to separate effects of these two events due to their chronological closeness, we investigate the Russian crisis only. The dot-com crisis was the following event that had a pronounced impact on the global financial system but we include the $9 / 11$ shock in our analysis as well since it represents an important non-financial event that affected financial markets globally in that period. The next important event was the subprime mortgage crisis. It started in United States and propagated to the rest of the world through the financial system, in which emerging European countries were particularly affected. This makes it especially interesting as an event that affected the Croatian financial market as well. Finally, as well as a wider set of economic, social and political effects, EU accession implies the intensification of financial integration between Croatian and European markets. Therefore, it is important to analyse how EU accession affected co-movements among Croatian and other markets.

The analysis of Croatian international stock market integration is of interest to investors looking for diversification opportunities in emerging European countries. Investors who seek financing on the local capital market will be better informed about assessing risk related to the channels of financial shock propagation. The emerging European countries experienced a larger drop in economic activity in the recent financial crisis than other regions (Berglof et al., 2009), so the implications of this study have relevance for domestic macroeconomic and monetary policy. Melitz and Zumer (1999) and Baele et al. (2004) claim that integrated European capital markets may decrease risk and allow for better diversification, while Kassim (2010) states that the extent of integration is highly relevant in the context of countries aiming for macroeconomic harmonization. Therefore, the financial stability of emerging European markets is important for the stability of the whole region and also has implications for the economic stability of the EU.

We contribute to the existing literature in several ways. Firstly, we use data on the longest time span available and are therefore able to investigate the full history of Croatian stock market co-movements. This allows us to go into detail about different events during that period and put them in a comparative perspective. This is especially interesting with respect to Croatia's EU accession, which was later than that of other new member states and should be analysed as a separate event. Secondly, our methodological approach makes use of both the dynamic conditional correlation model (DCC) of Engle and Sheppard (2001) and the asymmetric dynamic conditional correlation model (ADCC) of Cappiello et al. (2006a). It is reasonable to assume that correlations between Croatian and other stock markets are time-varying, these models accordingly being able to account for changing dynamics of the correlation structure and suitable for analysing different financial crises and events. Furthermore, by using both, symmetric and asymmetric volatility 
models we are able to check the impact of positive and negative news (shocks) on volatility. Thirdly, we analyse the co-movements between Croatian and different European and global markets, which allows us to inspect whether different financial incidents and other analysed events drive the correlation structure of these markets. Since similarities in the correlation of returns between different markets imply their closer integration we are also able to make some general conclusions about the structure of financial integration and transmission of global and regional financial shocks.

Our results suggest that the overall level of Croatian international financial integration is relatively low, average correlation in the full period amounting to around 0.25 , compared to developed markets. However, there are some tendencies of cross-market correlations to converge over time, which reduces Croatian international market segmentation. The analysis also shows that the subprime crisis had the strongest effect on international market integration, whereas Croatia's EU accession caused correlation coefficients to converge and somewhat reduced international market segmentation.

The article is organized as follows: section 2 gives an overview of related literature, while section 3 describes the data set and describes the empirical model. Section 4 presents the results and discusses implications. Concluding remarks are given in section 5 .

\section{RELATED LITERATURE}

One of the main interests of the literature about short and long term relationships between stock markets in emerging European countries has been in implications of results for portfolio diversification opportunities. The findings of the literature have been somewhat mixed but mostly point to regional stock market interdependence and imply that there are only limited diversification opportunities for investors in emerging European countries. The results show that there is a longrun relationship among emerging EU stock markets, but much less evidence has been found on the relationship between them and world markets. This is supported in MacDonald (2001) and Voronkova (2004), which do not find any significant benefits of portfolio diversification when investing in emerging EU stock markets due to their high degree of integration. Their results confirm that co-movement among emerging European markets is much stronger than the relationship between these markets and other world markets. Egert and Kocenda (2007) find some evidence in favour of stock market co-movement among the Czech Republic, Hungary, Poland, and developed European stock markets, but they conclude that portfolio diversification in these markets can still have some advantages.

Several papers analysed how various financial incidents and important events affected the integration of emerging European countries. The results show that different events affect these markets differently and more generally, that there is significant amount of heterogeneity within the sample. Syriopoulos (2004) investi- 
gates the impact of the European Monetary Union on international stock market integration among emerging EU countries and the developed markets of Germany and the United States. The author finds a co-integrating relationship between every analysed country pair and therefore confirms the long-term relationship among those markets. Cappiello et al. (2006b) find that the 2004 EU enlargement increased the international stock market integrations of the new EU members with each other and with EU countries in the period before EU accession. They find that the three largest new EU member states (the Czech Republic, Hungary, and Poland) are much more integrated with each other and with the EU than the smaller countries (Cyprus, Estonia, Latvia, and Slovenia), which do not co-move with each other.

Wang and Moore (2008) use a dynamic conditional correlation model to study the interdependence of the Czech, Hungarian, Polish and other EU markets. The authors find that the EU accession and the subprime crisis increased the degree of integration of new EU members and other European markets. Kenourgios et al. (2009) extends the dynamic conditional correlation model with structural breaks to analyse how several financial incidents affected stock market co-movements between developed EU countries, emerging EU countries, and Balkan countries. They find that the dot-com crisis, Euro introduction, and EU enlargement, as well, increased interdependence in these markets.

The literature has been focused on differently defined groups of emerging European countries, which makes it hard to draw clear conclusions about the financial integration of the whole group. Overall, results show that these countries are differently integrated into European and global financial markets. Furthermore, new member states are characterized by a higher degree of financial integration whereas South-Eastern European countries have a somewhat lower degree of financial integration into global and European financial systems. Syriopulos and Roumps (2009) analyse the integration of Balkan countries' stock markets with the German and US markets. The results show that developed markets affect Balkan markets in the long term and that correlations among them are dynamic and asymmetric. Egert and Kocenda (2011) analyse the Czech, Hungarian, and Polish stock markets' correlation with developed EU countries by using intraday trading data. They find very weak correlations among all the analysed countries, from which they conclude that financial shocks in developed markets have a delayed effect on the emerging EU stock markets. Furthermore, the EU accession effect is found to increase the integration of the analysed markets into world financial markets. Gjika and Horvath (2012) study stock market co-movements among the Czech Republic, Hungary, and Poland. Their results show that the correlation among the analysed stock markets rose steadily from 2001 onwards. EU accession and the subprime crisis positively affected their integration process. The authors find that correlations between stock market returns are characterized by asymmetric conditional variances and correlations.

In a recent study of the financial integration of South and East European countries with western European markets, Horvat and Petrovski (2013) find that the stock 
market integration of Central Europe vis-à-vis Western Europe is much higher than the integration of South-Eastern Europe vis-à-vis Western Europe. Their results show that Croatia has a positive integration trend and higher degree of financial integration than other South-Eastern European countries due to growing economic integration with the EU. Ivanov (2014) examines the return and volatility spill-overs and stock market co-movements among Western, Central and Southeast European stock markets. The results confirm a high and stable conditional correlation between Central and Western European markets. The conditional correlation between the Croatian market and developed markets is found to be modest but increasing.

Overall, the literature on the stock market integration of emerging European countries is characterized by several heterogeneities, and results have been somewhat mixed. The methodological approach differs among papers which makes it hard to compare the results directly. The literature has focused on different samples of countries, so that drawing implications about the financial integration of the whole region is not straightforward. However, the results confirm a significant mutual financial interdependence among emerging European countries but a somewhat lower degree of their integration into global financial system. The financial integration is generally higher for new member states and central European countries than for Balkan and South European countries. Finally, the results imply that different events and financial incidents have different impacts on this region but usually lead to more integration.

\section{DATA AND MODEL SELECTION}

We collected data on closing prices for CROBEX and several other stock markets market indices: S\&P500, STOXX600, FTSE100, DAX, ATX, WIG20, PX, and BUX. The data are daily and span the period from 3 September 1997 to 19 August 2016 for all indices. The prices are in HRK for the CROBEX index, US\$ for S\&P500, PLN for WIG20 and EUR for all other indices. The data were collected from Reuters DataStream service. We calculated the return series as:

$$
R_{i, t}=\ln \left(I_{i, t}\right)-\ln \left(I_{i, t-1}\right)
$$

where $I_{i, t}$ is the index price of the $i$-th country at time $t, I_{i, t-1}$ is the index price of the same country in the previous period, and $R_{i, t}$ is the corresponding rate of return of the index.

Figure 1 shows the return series of all the analysed stock market indices. It can be seen that all series exhibit clustering volatility. Periods of high volatility returns are common to all indices, especially during the recent financial economic crisis, when historically high extreme return values were observed. It can also be seen that the return series of the CROBEX index follows a relatively smooth pattern with few volatility clusters except during the recent economic crisis period. 
Figure 1

Return plots of the series
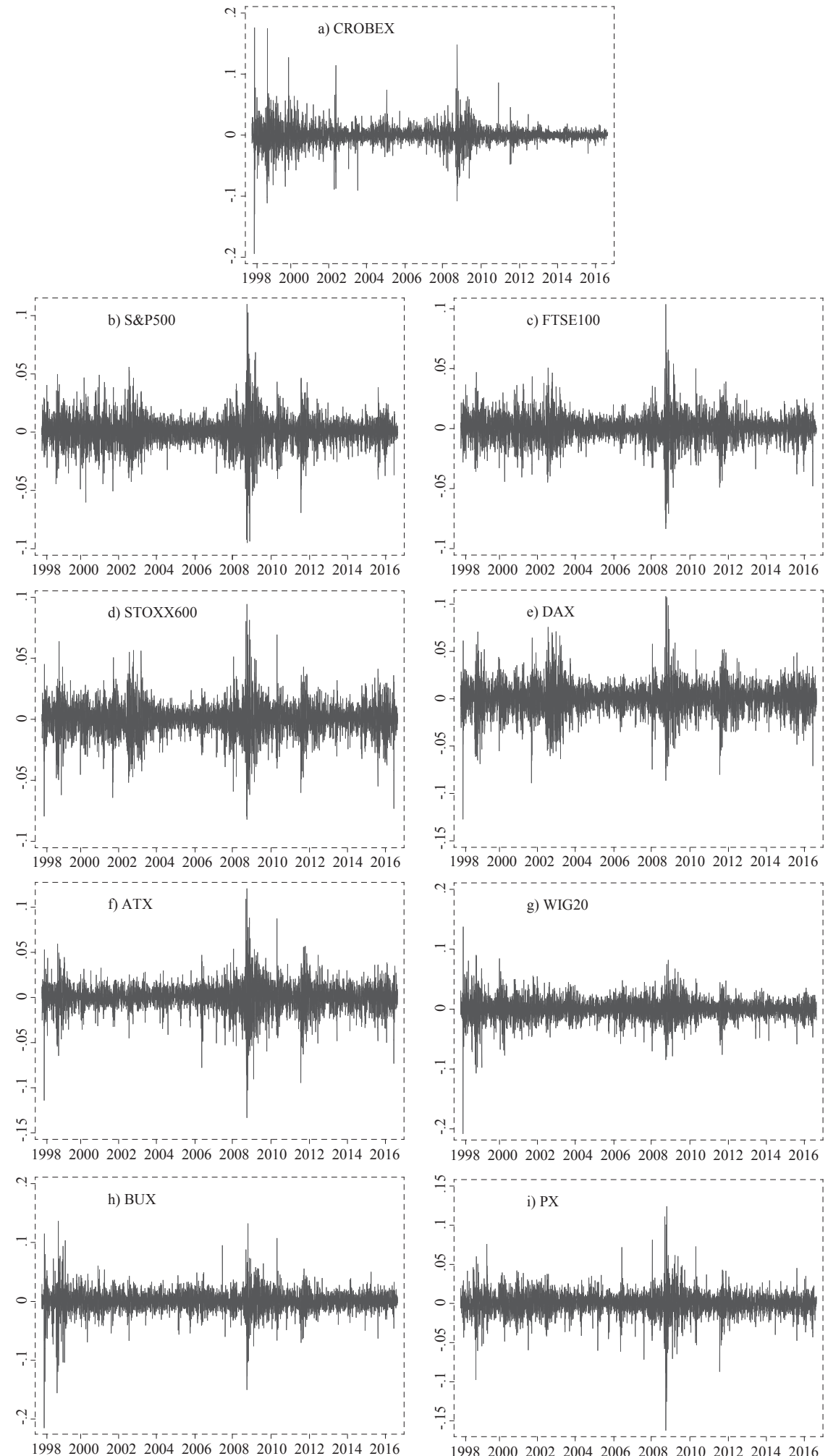
Table 1 provides descriptive statistics for all of the return series. The highest and lowest extreme values are observed for the ZSE, WIG20, BUX and PX indexes. Furthermore, the standard deviation shows that the returns of the FTSE100 and S\&P500 are the least volatile. Excess kurtosis is reported for all return series and implies non-normality of distribution. Non-normality is also confirmed via rejection of the Jarque-Berra test null-hypothesis. The ARCH effects were found by means of ARCH (10) tests. We applied the augmented DickeyFuller (ADF) to check the presence of unit roots in the return data. As table 1 reveals, all index return series are found to be stationary since ADF rejects the null of a unit root at the $1 \%$ level.

\section{TABle 1}

Descriptive statistics of return series

\begin{tabular}{|c|c|c|c|c|c|c|c|c|c|}
\hline & ZSE & S\&P500 & FTSE100 & STOXX600 & ATX & DAX & BUX & PX & WIG20 \\
\hline Mean & 0.000 & 0.000 & 0.000 & 0.000 & 0.000 & 0.000 & 0.000 & 0.000 & 0.000 \\
\hline Median & 0.000 & 0.000 & 0.000 & 0.000 & 0.000 & 0.000 & 0.000 & 0.000 & 0.000 \\
\hline Max. & 0.175 & 0.109 & 0.103 & 0.094 & 0.120 & 0.107 & 0.136 & 0.123 & 0.137 \\
\hline Min. & -0.194 & -0.094 & -0.083 & -0.081 & -0.133 & -0.127 & -0.214 & $\overline{-0.161}$ & -0.207 \\
\hline Std. dev. & 0.015 & 0.012 & 0.010 & 0.013 & 0.014 & 0.015 & 0.017 & 0.014 & 0.017 \\
\hline Skewness & -0.054 & -0.194 & -0.255 & -0.285 & -0.546 & -0.241 & -0.778 & $\overline{-0.476}$ & -0.506 \\
\hline Kurtosis & 24.923 & 10.606 & 9.869 & 8.021 & 11.095 & 7.622 & 16.693 & $\overline{14.274}$ & 11.836 \\
\hline $\begin{array}{l}\text { Jarque- } \\
\text { Berra } \\
\text { (p-value) }\end{array}$ & $(0.000)$ & $(0.000)$ & $(0.000)$ & $(0.000)$ & $(0.000)$ & $(0.000)$ & $.000)$ & .000) & $(0.000)$ \\
\hline No. obs. & 4,650 & 4,650 & 4,650 & 4,632 & 4,632 & 4,632 & 4,632 & 4,648 & 4,632 \\
\hline $\mathrm{ADF}$ & -18.222 & -16.60064 & -20.567 & -20.954 & -22.719 & -20.399 & -21.693 & 22.471 & -23.877 \\
\hline Probability & $(0.000)$ & $(0.000)$ & $(0.000)$ & $(0.000)$ & $(0.000)$ & $\overline{(0.000)}$ & $\overline{(0.000)}$ & $\overline{(0.000)}$ & $(0.000)$ \\
\hline $\mathrm{ARCH}(10)$ & 135.490 & 167.816 & 178.484 & 100.647 & 130.147 & 77.540 & 83.972 & 63.246 & 55.157 \\
\hline Probability & $(0.000)$ & $(0.000)$ & $(0.000)$ & $(0.000)$ & $(0.000)$ & $\overline{(0.000)}$ & $\overline{(0.000)}$ & $\overline{(0.000)}$ & $(0.000)$ \\
\hline
\end{tabular}

\subsection{MODEL SELECTION}

The asymmetric volatility in the covariance of different assets emerges due to differential volatility reaction to negative and positive shocks of the same magnitude. Furthermore, the existence of declining correlations between stock markets during the rising trends, rising correlations during the negative trends and generally higher correlations during the volatile periods imply that correlations between stock markets are dynamic and time dependent. Therefore, these correlations should be measured with proper dynamic correlation models that are able to account for time variation in the correlation structure. Here we find the dynamic conditional correlation model of Engle and Sheppard (2001) and the asymmetric dynamic conditional correlation model of Cappiello et al. (2006a) particularly suitable.

Our methodological procedure consists of two steps. In the first part we find the best-fitted GARCH model among several possibilities: Bollerslev's (1986) GARCH model, the exponential GARCH model of Nelson (1991), and the GJR-GARCH model of Glosten et al. (1993). In the second part we feed the residuals from the 
The residuals from the best fit GARCH model in the first stage are fed into the dynamic conditional correlation model of Engle and Sheppard (2001) and the asymmetric dynamic conditional correlation model of Cappiello et al. (2006a) in the second stage of the estimation. We then selected the best model between the two via AIC criteria. The dynamic conditional correlation model is defined as:

$$
r_{t} \mid I_{t-1} \sim N\left(0, H_{t}\right)
$$

where $r_{t}$ is the return series, assumed to be normally distributed with a mean of zero, and $I_{t-1}$ is the information set available in the previous period. $H_{t}$ is a conditional covariance matrix assumed to be positive definite:

$$
H_{t}=D_{t} R_{t} D_{t}
$$

where $D_{t}$ is a diagonal matrix of time-dependent volatilities from univariate GARCH models obtained in the first step that takes the shape:

$$
D_{t}=\left[\begin{array}{cc}
\sqrt{\sigma_{1, t}^{2}} & 0 \\
0 & \sqrt{\sigma_{2, t}^{2}}
\end{array}\right]
$$

$R_{t}$ is a time-varying correlation matrix of standardized residuals $\varepsilon_{t}=D_{t}^{-1} r_{t} \sim N\left(0, R_{t}\right)$ that takes the shape:

$$
R_{t}=\left[\begin{array}{cc}
1 & \rho_{12, t} \\
\rho_{21, t} & 1
\end{array}\right]
$$

where $\rho_{12, t}=\frac{E_{t-1}\left(q_{1, t q_{2, t}}\right)}{\sqrt{E_{t-1}\left(q_{1, t}^{2}\right) E_{t-1}\left(q_{2, t}^{2}\right)}}$ is the conditional correlation estimation between two returns. The elements of $R_{t}$ are obtained by using a series of standardized residuals as $R_{t}=Q_{t}^{*-0.5} Q_{t} Q_{t}^{*-0.5}$ where:

$$
Q_{t}=(1-\alpha-\beta) \bar{Q}+\alpha \varepsilon_{t-1} \varepsilon_{t-1}^{\prime}+\beta Q_{t-1}
$$

is the conditional covariance matrix of standardized residuals and describes the dynamic structure of the model, and $Q_{t}^{*}$ is the diagonal matrix with the square root of the $i$-th standardized residual. The $\varepsilon_{t}$ is the residual series from the first step of the estimation procedure, and $\bar{Q}=\mathrm{E}\left[\varepsilon_{t} \varepsilon_{t}^{\prime}\right]$ is the unconditional correlation matrix of the standardized residuals. The scalars $\alpha$ and $\beta$ contain information on the effects of previous shocks and dynamic conditional correlations on current dynamic conditional correlations. 
Cappiello et al. (2006a) extends the dynamic conditional correlation model so that it is able to factor in the heterogeneity of shock impacts on the correlation structure. The paper proposes an asymmetric dynamic conditional correlation model, where the dynamic structure of the model evolves according to the following equation:

$$
Q_{t}=(1-\alpha-\beta) \bar{Q}-\eta \bar{N}+\alpha \varepsilon_{t-1} \varepsilon_{t-1}^{\prime}+\beta Q_{t-1} \eta n_{t-1} n_{t-1}^{\prime}
$$

where $\alpha, \beta, \eta$ are estimated parameters, $\eta$ contains the asymmetric effects, $\varepsilon_{t}$ contains the residual series from the first estimation step, $\bar{Q}$ is an unconditional covariance matrix of residuals, $n_{t}=l\left(\varepsilon_{t}<0\right) \cdot \varepsilon_{t}{ }^{1}$ is the matrix of asymmetric shocks, and $\bar{N}$ is an unconditional covariance matrix of $n_{t}$.

The estimation of the DCC model and the ADCC model is done via maximization of the quasi log likelihood function²:

$$
L=-\frac{1}{2} \sum_{t=1}^{T}\left(n \log (2 \pi)+2 \log \left|D_{t}\right|+r_{t}^{\prime} D_{t}^{-2} r_{t}-\varepsilon_{t}^{\prime} \varepsilon_{t}+\log \left|R_{t}\right|+\varepsilon_{t}^{\prime} R_{t}^{-1} \varepsilon_{t}\right.
$$

\section{RESULTS OF THE EMPIRICAL ANALYSIS}

The results of our analysis and subsequent discussion are presented in this section. First, we present the results for the full sample period and then proceed to the analysis of separate events that affected financial markets. The simple correlation coefficients are given in table 2 where relatively low average correlations can be observed. The results show that average correlations among markets are relatively similar and range between 0.25 and 0.31 . The lower average correlation among CROBEX, S\&P500 and FTSE100 stands somewhat in contrast to higher observed correlations with other developed and emerging European markets. This might imply a weaker integration of Croatian stock exchange into the global financial system and the greater importance of European and regional markets. Compared to the dynamic conditional correlation estimates from the table $3 \mathrm{C}$, the simple average correlation coefficients show relatively similar values. However, within period trends between these two estimates differ significantly. The difference might be due to time variation of the correlation structure that dynamic conditional correlation estimates are able to capture.

The results of the best fitted GARCH models are presented in table 3A. The AIC criterion was used to find the best fitted model among GARCH, EGARCH and GJRGARCH alternatives. The results are along the lines of Dajcman (2013) who finds that univariate stock market returns have different best fit ARCH/GARCH models. A robustness check was also done with SIC criteria, and the results did not change. The parameter $\omega$ is the constant of the estimated model, $\alpha$ informs about the impact of past shocks, and $\beta$ about the impact of past volatilities on the current

${ }^{1} l\left(\varepsilon_{t}<0\right)$ is a $1 x k$ indicator function that takes on the value 1 when $\varepsilon_{t}<0$ and 0 in other cases.

${ }^{2}$ Since the tests for the residuals of our univariate GARCH models show that they are not normally distributed. 
conditional volatility. The leverage effects are captured in the parameter $\gamma$, which indicates the presence of asymmetric effects in the conditional variance for certain models. A bigger estimated $\alpha$ coefficient indicates stronger volatility reaction to the shock, a larger estimated $\beta$ implies stronger volatility persistence (the shocks take longer to die out) and statistically different than zero $\gamma$ coefficient informs about the presence of asymmetric effects in the conditional variance. For the overall period, the $\alpha$ coefficient ranges between 0.009 and 0.098 so it is possible to say that the reaction to news is strongest for FTSE100 index and weakest for STOXX600. It is worth noticing that $\alpha$ coefficient for CROBEX index also takes a high value (0.096) relative to other analysed markets. The $\beta$ coefficient varies between 0.878 for BUX index and 0.976 for ATX which means that the shortest time is needed for a shock's impact on volatility to die out in the Hungarian and the longest in the Austrian stock exchange. This is similar to the results of Wang and Moore (2008), which also finds high persistence (parameter estimate close to one) of shocks on volatility. Statistically significant $\gamma$ coefficient is observed for ATX, BUX, PX and WIG20 which means that positive news has a differential impact on the conditional variance relative to negative news. Therefore, these indices show asymmetric reactions to news. This result is again close to Wang and Moore (2008), which finds asymmetric reaction for every analysed emerging European market and Gijka and Horvath (2012), which finds asymmetry in conditional variance for BUX, PX and WIG index.

\section{TABLe 2}

Simple correlation coefficients for the full sample period (annual averages)

\begin{tabular}{|c|c|c|c|c|c|c|c|c|}
\hline Year & S\&P500 & FTSE100 & DJSTOXX & ATX & DAX & BUX & PX & WIG20 \\
\hline 1997 & 0.340 & 0.616 & 0.432 & 0.716 & 0.749 & 0.689 & 0.811 & 0.823 \\
\hline 1998 & 0.211 & 0.378 & 0.350 & 0.494 & 0.459 & 0.490 & 0.577 & 0.494 \\
\hline 1999 & 0.051 & -0.001 & 0.107 & 0.222 & 0.140 & 0.238 & 0.313 & 0.307 \\
\hline 2000 & 0.041 & 0.014 & 0.119 & 0.135 & 0.161 & 0.059 & 0.207 & 0.261 \\
\hline 2001 & 0.059 & 0.047 & 0.145 & 0.278 & 0.117 & 0.222 & 0.202 & 0.181 \\
\hline 2002 & -0.053 & -0.079 & -0.011 & 0.068 & 0.093 & 0.036 & 0.095 & 0.094 \\
\hline 2003 & 0.184 & 0.026 & 0.212 & 0.213 & 0.086 & 0.202 & 0.133 & 0.139 \\
\hline 2004 & 0.045 & -0.016 & 0.110 & 0.172 & 0.163 & 0.158 & 0.066 & 0.075 \\
\hline 2005 & 0.021 & 0.008 & 0.042 & 0.074 & 0.101 & 0.030 & 0.139 & 0.109 \\
\hline 2006 & -0.029 & 0.015 & 0.037 & 0.102 & 0.131 & 0.092 & 0.216 & 0.100 \\
\hline 2007 & 0.095 & 0.058 & 0.226 & 0.285 & 0.306 & 0.285 & 0.253 & 0.277 \\
\hline 2008 & 0.474 & -0.129 & 0.668 & 0.673 & 0.658 & 0.672 & 0.545 & 0.563 \\
\hline 2009 & 0.360 & 0.009 & 0.547 & 0.605 & 0.574 & 0.557 & 0.375 & 0.505 \\
\hline 2010 & 0.230 & -0.045 & 0.339 & 0.353 & 0.363 & 0.313 & 0.312 & 0.355 \\
\hline 2011 & 0.302 & -0.095 & 0.385 & 0.463 & 0.498 & 0.448 & 0.364 & 0.417 \\
\hline 2012 & 0.272 & -0.046 & 0.353 & 0.346 & 0.392 & 0.366 & 0.240 & 0.281 \\
\hline 2013 & 0.059 & 0.031 & 0.089 & 0.130 & 0.077 & 0.132 & 0.051 & 0.044 \\
\hline 2014 & 0.193 & 0.070 & 0.217 & 0.225 & 0.136 & 0.184 & 0.086 & 0.184 \\
\hline 2015 & 0.220 & -0.073 & 0.237 & 0.251 & 0.232 & 0.230 & 0.174 & 0.226 \\
\hline 2016 & 0.290 & -0.016 & 0.361 & 0.398 & 0.350 & 0.386 & 0.345 & 0.211 \\
\hline Average & 0.168 & 0.039 & 0.248 & 0.310 & 0.289 & 0.289 & 0.275 & 0.282 \\
\hline
\end{tabular}


TABLE 3A

Selected univariate GARCH models and parameter estimation results for the full sample period

\begin{tabular}{|c|c|c|c|c|c|c|c|}
\hline Index & Model & $\omega$ & $\alpha$ & $\beta$ & $\gamma$ & $\log l$ & AIC \\
\hline CROBEX & sGARCH & $\begin{array}{c}0.012 \\
(0.000)\end{array}$ & $\begin{array}{c}0.096 \\
(0.000)\end{array}$ & $\begin{array}{c}0.902 \\
(0.000)\end{array}$ & - & $-7,095.87$ & 3.053 \\
\hline S\&P500 & sGARCH & $\begin{array}{c}0.049 \\
(0.000) \\
\end{array}$ & $\begin{array}{c}0.089 \\
(0.000)\end{array}$ & $\begin{array}{c}0.897 \\
(0.000)\end{array}$ & - & $-6,730.90$ & 2.896 \\
\hline FTSE100 & sGARCH & $\begin{array}{c}0.014 \\
(0.000) \\
\end{array}$ & $\begin{array}{c}0.098 \\
(0.000)\end{array}$ & $\begin{array}{c}0.891 \\
(0.000)\end{array}$ & - & $-6,220.28$ & 2.677 \\
\hline STOXX600 & sGARCH & $\begin{array}{c}0.024 \\
(0.000)\end{array}$ & $\begin{array}{c}0.009 \\
(0.173)\end{array}$ & $\begin{array}{c}0.899 \\
(0.000)\end{array}$ & - & $-6,912.23$ & 2.986 \\
\hline ATX & eGARCH & $\begin{array}{c}0.013 \\
(0.000)\end{array}$ & $\begin{array}{c}0.090 \\
(0.000)\end{array}$ & $\begin{array}{c}0.976 \\
(0.000)\end{array}$ & $\begin{array}{c}0.0448 \\
(0.004)\end{array}$ & $-7,427.90$ & 3.209 \\
\hline DAX & gjrGARCH & $\begin{array}{c}0.035 \\
(0.000)\end{array}$ & $\begin{array}{c}0.018 \\
(0.003)\end{array}$ & $\begin{array}{c}0.898 \\
(0.000)\end{array}$ & $\begin{array}{c}0.027 \\
(0.110)\end{array}$ & $-7,911.81$ & 3.418 \\
\hline BUX & eGARCH & $\begin{array}{c}0.039 \\
(0.000)\end{array}$ & $\begin{array}{c}0.017 \\
(0.003)\end{array}$ & $\begin{array}{c}0.878 \\
(0.000)\end{array}$ & $\begin{array}{c}0.029 \\
(0.000)\end{array}$ & $-8,111.81$ & 3.497 \\
\hline PX & gjrGARCH & $\begin{array}{c}0.041 \\
(0.000)\end{array}$ & $\begin{array}{c}0.017 \\
(0.003)\end{array}$ & $\begin{array}{c}0.925 \\
(0.000)\end{array}$ & $\begin{array}{c}0.036 \\
(0.000)\end{array}$ & $-7,727.90$ & 3.312 \\
\hline WIG20 & gjrGARCH & $\begin{array}{c}0.044 \\
(0.000)\end{array}$ & $\begin{array}{c}0.016 \\
(0.005)\end{array}$ & $\begin{array}{c}0.944 \\
(0.000)\end{array}$ & $\begin{array}{c}0.040 \\
(0.000)\end{array}$ & $-8,561.01$ & 3.698 \\
\hline
\end{tabular}

\section{TABLE 3B}

Selected bivariate asymmetric dynamic conditional correlation models and parameter estimation results for the full sample period

\begin{tabular}{|c|c|c|c|c|c|c|}
\hline Index pairs & Model & $\alpha$ & $\beta$ & $\gamma$ & Logl & AIC \\
\hline CROBEX - S\&P500 & DCC & $\begin{array}{c}0.007 \\
(0.001)\end{array}$ & $\begin{array}{c}0.989 \\
(0.000)\end{array}$ & - & $-13,759.50$ & 5.922 \\
\hline CROBEX - FTSE100 & $\mathrm{DCC}$ & $\begin{array}{c}0.016 \\
(0.003)\end{array}$ & $\begin{array}{c}0.978 \\
(0.000)\end{array}$ & - & $-13,157.02$ & 5.663 \\
\hline CROBEX - STOXX600 & $\mathrm{ADCC}$ & $\begin{array}{c}0.019 \\
(0.001)\end{array}$ & $\begin{array}{c}0.968 \\
(0.000)\end{array}$ & $\begin{array}{c}0.005 \\
(0.338)\end{array}$ & $-13,846.02$ & 5.973 \\
\hline CROBEX - ATX & $\mathrm{ADCC}$ & $\begin{array}{c}0.022 \\
(0.000)\end{array}$ & $\begin{array}{c}0.960 \\
(0.000)\end{array}$ & $\begin{array}{c}0.007 \\
(0.500)\end{array}$ & $-14,364.07$ & 6.196 \\
\hline CROBEX - DAX & $\mathrm{ADCC}$ & $\begin{array}{c}0.019 \\
(0.001)\end{array}$ & $\begin{array}{c}0.962 \\
(0.000)\end{array}$ & $\begin{array}{c}0.008 \\
(0.375)\end{array}$ & $-14,774.70$ & 6.374 \\
\hline CROBEX - BUX & DCC & $\begin{array}{c}0.018 \\
(0.001)\end{array}$ & $\begin{array}{c}0.952 \\
(0.000)\end{array}$ & - & $-14,763.90$ & 6.467 \\
\hline CROBEX - PX & DCC & $\begin{array}{c}0.017 \\
(0.001)\end{array}$ & $\begin{array}{c}0.976 \\
(0.000\end{array}$ & - & $14,257.03$ & 6.033 \\
\hline CROBEX - WIG20 & DCC & $\begin{array}{l}0.0055 \\
(0.068)\end{array}$ & $\begin{array}{c}0.986 \\
(0.000)\end{array}$ & - & $-15,452.06$ & 6.666 \\
\hline
\end{tabular}

Table 3B shows the parameter estimates of the best-fit A/DCC model, which was chosen so as to minimize AIC criteria. The parameters $\alpha$ and $\beta$ are significant in every analysed case and show that past shocks and lagged correlations impact the current conditional correlation. Although the best bivariate correlation model for CROBEX and STOXX600 and for ATX and DAX is ADCC, the asymmetry 
parameter $\gamma$ is found to be statistically insignificant in all cases. This means that positive and negative news have the same effect on the co-movements between Croatian and other analysed markets. This finding generally complies with Syriopulos and Roumps (2009), which confirms asymmetry in correlations structure of Balkan countries as well as Gijka and Horvath (2012), which finds asymmetry in conditional variances but much less asymmetry in conditional correlation in the sample of Central European stock markets.

To be able to understand the trend of the dynamic correlations between the emerging Croatian and other analysed stock markets, we compute the annual averages of the daily dynamic conditional correlations. The results are shown in table $3 \mathrm{C}$ and figure 2. The computed correlations inform us about the degree of international integration of the Croatian market with other markets.

\section{TABLE 3C}

Dynamic conditional correlation estimates for the full sample period (annual averages)

\begin{tabular}{|c|c|c|c|c|c|c|c|c|}
\hline Year & S\&P500 & FTSE100 & DJSTOXX & ATX & DAX & BUX & PX & WIG20 \\
\hline 1997 & 0.169 & 0.239 & 0.429 & 0.465 & 0.437 & 0.480 & 0.194 & 0.542 \\
\hline 1998 & 0.226 & 0.329 & 0.405 & 0.407 & 0.414 & 0.483 & 0.286 & 0.402 \\
\hline 1999 & 0.138 & 0.189 & 0.270 & 0.248 & 0.259 & 0.343 & 0.287 & 0.296 \\
\hline 2000 & 0.053 & 0.125 & 0.201 & 0.213 & 0.141 & 0.238 & 0.212 & 0.307 \\
\hline 2001 & 0.085 & 0.154 & 0.263 & 0.177 & 0.237 & 0.231 & 0.183 & 0.268 \\
\hline 2002 & 0.028 & 0.058 & 0.154 & 0.142 & 0.131 & 0.195 & 0.113 & 0.245 \\
\hline 2003 & 0.160 & 0.222 & 0.254 & 0.158 & 0.242 & 0.215 & 0.188 & 0.240 \\
\hline 2004 & 0.136 & 0.171 & 0.216 & 0.213 & 0.198 & 0.189 & 0.186 & 0.215 \\
\hline 2005 & 0.070 & 0.091 & 0.148 & 0.166 & 0.133 & 0.198 & 0.195 & 0.233 \\
\hline 2006 & -0.010 & 0.049 & 0.151 & 0.168 & 0.147 & 0.253 & 0.215 & 0.225 \\
\hline 2007 & 0.074 & 0.180 & 0.244 & 0.249 & 0.249 & 0.233 & 0.212 & 0.297 \\
\hline 2008 & 0.187 & 0.409 & 0.475 & 0.446 & 0.462 & 0.339 & 0.394 & 0.415 \\
\hline 2009 & 0.307 & 0.474 & 0.503 & 0.469 & 0.457 & 0.343 & 0.420 & 0.385 \\
\hline 2010 & 0.253 & 0.351 & 0.368 & 0.363 & 0.334 & 0.306 & 0.366 & 0.350 \\
\hline 2011 & 0.210 & 0.258 & 0.303 & 0.294 & 0.288 & 0.250 & 0.262 & 0.299 \\
\hline 2012 & 0.273 & 0.356 & 0.344 & 0.348 & 0.342 & 0.277 & 0.306 & 0.312 \\
\hline 2013 & 0.114 & 0.140 & 0.215 & 0.176 & 0.205 & 0.199 & 0.184 & 0.231 \\
\hline 2014 & 0.154 & 0.205 & 0.238 & 0.183 & 0.225 & 0.199 & 0.164 & 0.277 \\
\hline 2015 & 0.190 & 0.205 & 0.225 & 0.222 & 0.221 & 0.238 & 0.230 & 0.297 \\
\hline 2016 & 0.222 & 0.299 & 0.338 & 0.306 & 0.332 & 0.292 & 0.307 & 0.283 \\
\hline Average & 0.152 & 0.225 & 0.287 & 0.271 & 0.273 & 0.275 & 0.245 & 0.306 \\
\hline
\end{tabular}

The results show that the full-period average correlation of the Croatian stock exchange with other analysed markets is relatively small, around 0.25 . This shows a relatively low level of international financial integration, especially compared to the 0.6 found for Central European stock markets (see Horvath and Petrovski, 2013). The authors also find higher correlations for Croatian market than reported here but both correlation dynamics follow a very similar trend. This might be due to the difference in applied methodologies. Our results are similar to those of 
Ivanov (2014), which reports modest levels of financial integration for Croatian market. However, the author finds that integration levels have a rising trend over time, which could not be confirmed in our analysis.

\section{Figure 2}

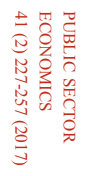

\section{Conditional correlations from the estimated A/DCC model}
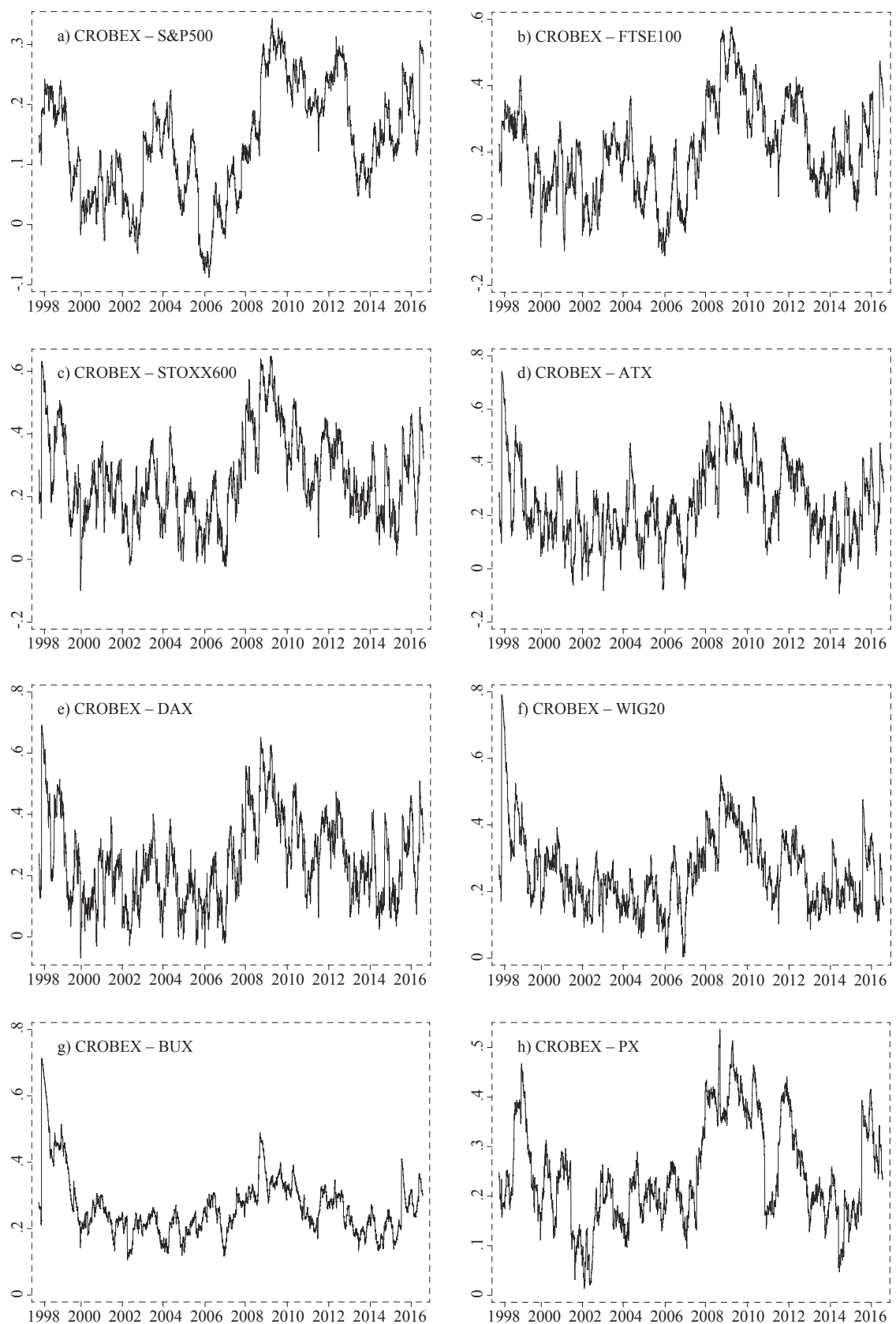
The generally low to modest financial integration levels reflect the short history of the Croatian stock exchange, small market capitalization, banking-oriented domestic financial system and weak long term economic growth. The degree of Croatian stock market integration is lowest with the US and UK markets and highest with the Polish and Hungarian market. The overall integration is strongest with nearby markets and seems to be influenced by the gravity effect. This could reflect historical ties and economic similarities of the countries in the region where regional investors are better informed about trends and developments in their neighbourhood and can better assess risk and profit opportunities.

The initial integration levels of the Croatian market with other European markets are quite high, while its integration with the US and UK markets is relatively low. Its integration dynamics with all markets has a falling trend until 2003, after which it stays relatively low all the way up to the subprime crisis. Some divergence of integration trends can be observed between US and UK markets on one side and all other European markets on the other. This might point to a different degree of integration and shock transmission dynamics from global (US, UK) and European markets. Like Wang and Moore (2008) we find that the subprime crisis caused a drastic rise of correlation among all of the observed indices, where the biggest relative increase of correlation coefficients was observed for the UK and US markets. It is also interesting to note that it took almost a year longer for the CROBEX - S\&P500 pair to come to its integration peak than other indices which shows especially low Croatian financial integration with US markets and slow financial shock transmission from global markets. The period after the subprime crisis is also very interesting because there seems to be some convergence in correlation coefficients between Croatian and all other analysed markets, including the US and the UK. However, this could be related to Croatia's EU integration and accession process as well.

Next, we turn to the analysis of how four important events in the last two decades affected the process of international financial integration of the Croatian stock exchange.

\subsection{THE RUSSIAN CRISIS}

First we want to investigate the effect of the Russian currency crisis on the comovement of the Croatian stock market with other markets. To investigate the impacts of this incident, we split our sample into two periods. The first period is from the beginning of our sample, 3 September 1997, until the beginning of the Russian crisis on 16 August 1998 as reported by Forbes (2004). The second period starts on 17 August 1998 and ends on 31 December 1999. Ideally, we would want to split the sample into three periods so that the crisis period could be analysed separately, but due to the insufficiently long period of the crisis, we split the sample in two. 
Dynamic conditional correlation estimates for the Russian crisis (period averages)

\begin{tabular}{lllllllll} 
Pre-crisis & $\frac{\text { S\&P500 }}{0.241}$ & $\frac{\text { FTSE100 }}{0.329}$ & $\frac{\text { DJSTOXX }}{0.454}$ & $\frac{\text { ATX }}{0.747}$ & $\frac{\text { DAX }}{0.462}$ & $\frac{\text { BUX }}{0.493}$ & $\frac{\text { PX }}{0.213}$ & $\frac{\text { WIG20 }}{0.542}$ \\
\hline Post-crisis & $\frac{0.113}{0.198}$ & $\frac{0.297}{0.257}$ & $\frac{0.302}{0.371}$ & $\frac{0.309}{0.313}$ \\
\hline
\end{tabular}

The pre- and post-crisis period averaged correlation coefficients between the Croatian market and other markets are given in table $4 \mathrm{~A}$. The respective results of the univariate GARCH and A/DCC models are given in tables 4B-4F in the appendix. We can see that financial integration levels before the Russian crisis were quite high in general, whereas the integration levels with European markets were especially high. The results show that the Croatian stock market experienced a significant decrease in conditional correlations with all of the analysed markets in the post-crisis period. Since the integration levels of all analysed pairs decreased in the post-crisis period, we conclude that the Russian crisis caused the Croatian stock market to disintegrate with the world market and EU markets.

\subsection{THE DOT-COM AND 9/11 CRISES}

In this part we analyse the impact of the dot-com crisis and 9/11 shocks on the process of Croatian international stock market integration. The dot-com crisis started on 10 March 2000, when the NASDAQ index peaked and in the aftermath of that event, the United States faced another shock, the 9/11 terrorist attacks, so we assume that the joint impacts of these two shocks continued until the end of the 2002. We divided our sample into three periods: a pre-crisis period from 1 January 1999 until 9 March 2000; a crisis period from 10 March 2000 to 31 December 2002, and a post-crisis phase from 1 January 2002 until 31 December 2003.

\section{TABLE 5A}

Dynamic conditional correlation estimates for the dot-com and 9/11 crisis (period averages)

\begin{tabular}{|c|c|c|c|c|c|c|c|c|}
\hline & \&P500 & FTSE100 & DJSTOXX & ATX & DAX & BUX & PX & WIG20 \\
\hline & 0.057 & 0083 & 0.141 & 0.112 & 0.103 & 0.319 & 0.269 & 0.253 \\
\hline Cri & 0 & 78 & 0. & 7 & 18 & 0.2 & 0.168 & 91 \\
\hline ost-crisis & 0.127 & 0.165 & 0.182 & 0.122 & 0.175 & 0.214 & 0.188 & 0.104 \\
\hline
\end{tabular}

Table 5A shows the correlation coefficients between the Croatian market and each of the other analysed markets during the pre-crisis, crisis, and post-crisis periods. The results of the respective univariate $\mathrm{GARCH}$ and $\mathrm{A} / \mathrm{DCC}$ models are given in tables $5 \mathrm{~B}-5 \mathrm{G}$ in the appendix. We see that integration levels in the pre-crisis period are generally low for all markets but especially low for the US and UK markets. This implies that the Croatian stock market was not integrated into global markets before the dot-com and 9/11 events, although some degree of integration with European markets was present in the pre-crisis period. We generally observe a slight fall in correlation with most of the markets, but the crisis somewhat increased integration levels with the broad European and German markets to a 
minor extent. The fall in correlation with the US, UK, Austrian, and Polish markets was minor, so we conclude that there was no significant effect of these events on Croatian financial integration. The post-crisis period is characterized by rising correlations with all markets except the Polish market. However, it is worth noting that this increase was highest for the US and UK markets, which reached about the same integration levels as the other analysed European markets. We interpret that as the dot-com and 9/11 events benefitting Croatia's integration into the international financial system. It is also interesting to see that there has been some evidence of regional disintegration in the post-crisis period, specifically with the Polish market, which might point to a differential impact of global and regional financial shocks.

\subsection{THE SUBPRIME MORTGAGE CRISIS}

In this part we analyse the subprime crisis, an event that had a profound effect on global financial markets and developed into one of the biggest economic crises in modern history. The impact of this crisis was especially strong in emerging European countries and Croatia as well, causing a massive fall in index values in the stock market and a protracted recession in the real economy. To analyse the impact of the subprime mortgage crisis, we divided the sample into three periods: a precrisis period from 1 January 2005 until 31 July 2007; a crisis period from 1 August 2007 to 31 March 2009 (as defined in Manda, 2010); and a post-crisis period from 1 April 2009 until 31 December 2011.

\section{TABLE 6A}

Dynamic conditional correlation estimates for the subprime mortgage crisis (period averages)

\begin{tabular}{|c|c|c|c|c|c|c|c|c|}
\hline & S\&P500 & FTSE100 & DJSTOXX & ATX & DAX & BUX & PX & WIG20 \\
\hline Pre-crisis & 0.002 & 0.039 & 0.121 & 0.136 & 0.100 & 0.219 & 0.197 & 0.112 \\
\hline Crisis & 0.263 & 0.454 & 0.547 & 0.526 & 0.531 & 0.324 & 0.361 & 0.487 \\
\hline Post-crisis & 0.279 & 0.376 & 0.403 & 0.413 & 0.381 & 0.296 & 0.346 & 0.370 \\
\hline
\end{tabular}

The results of our analysis are shown in table 6A. The respective results of the univariate GARCH and A/DCC models are shown in tables 6B-6G in the appendix. It can be seen that integration levels of the Croatian market with all other analysed markets were very low in the pre-crisis period and that there was nearly zero co-movement with the US and UK markets. The subprime crisis caused correlation coefficients to rise dramatically, the biggest increases being with the US and UK markets. The integration levels of all markets rose to similar levels, which were among the highest in the overall analysed period. In the period after the crisis, the integration levels fell somewhat but stayed relatively high. This finding is similar to that of Horvat and Petrovski (2012), who document an increase in comovements in the period before the crisis and subsequent fall to lower but positive values after the crisis. 
We conclude that the subprime crisis was a global financial shock that affected all market correlations and possibly had a contagious effect on the Croatian stock market. The subprime mortgage crisis caused the Croatian stock market to become more integrated with the global and European markets, as well. Furthermore, the degree of integration was stable, since, during the post-crisis period, the integration levels stayed relatively high for all markets.

\subsection{EU ACCESSION}

The effect of Croatian EU accession on its international financial integration is analysed in this section. EU integration was a long-term process, in which negotiations started years before Croatia's actual joining of the EU. Since we wanted to minimize the overlapping of periods, we decided to split the sample into two periods: the announcement period from 1 July 2011, when the negotiations ended and the entry period was announced, until 1 July 2013, when Croatia joined the EU; and the post-accession period from 1 August 2013 to 31 December 2015.

\section{TABLE 7A}

Dynamic conditional correlation estimates for $E U$ accession (period averages)

\begin{tabular}{lcccccccc}
\hline Announcement & $\frac{\text { S\&P500 }}{0.370}$ & $\frac{\text { FTSE100 }}{0.305}$ & $\frac{\text { DJSTOXX }}{0.333}$ & $\frac{\text { ATX }}{0.364}$ & $\frac{\text { DAX }}{0.330}$ & $\frac{\text { BUX }}{0.262}$ & $\frac{\text { PX }}{0.286}$ & $\frac{\text { WIG20 }}{0.275}$ \\
\hline Post-accession & 0.169 & $\frac{0.184}{0.202}$ & $\frac{0.156}{0.219}$ & $\frac{0.213}{0.193}$ & $\frac{0.208}{0.202}$ \\
\hline
\end{tabular}

The results of the univariate GARCH and A/DCC models are given in tables 7B-7E in appendix. The results in table 7A show that integration levels during the announcement period were relatively high and very similar for all markets. This result is close to Cappiello et al. (2006b), which documents the increase in international financial integration of Central European markets in the period before EU accession. However, we see the main effects of EU accession in the reduction of Croatian financial market segmentation with global and EU markets and not necessarily in increasing its financial integration (see Egert and Kocenda, 2011). It is possible that investors perceived the Croatian market as less risky and that integration increased due to stronger integration in the EU financial system. The post-announcement period is characterized by a significant drop of correlation in all markets. It is interesting that the fall in correlation is relatively equal for all of the analysed markets, and we interpret this as the benefit that EU accession brings. In other words, the major effect of EU accession on the international financial integration of the Croatian market is less segmentation but not necessarily deeper integration.

\section{CONCLUSION}

This study investigates the history of the international stock market integration of Croatia. The focus of the analysis is on general integration trends in the last two decades as well as the effects of several regional and global financial events that characterize that period. We used asymmetric/dynamic conditional correlation models to analyse market co-movements (integration). Our results have implica- 
tions for international portfolio diversification strategies, address the literature on market efficiency, and provide information about the macroeconomic harmonization process in the enlarged EU.

Our data set is based on daily values of closing stock market index prices and spans the period from 3 September 1997 to 19 August 2016. We made use of this data to calculate index returns for every analysed market and use it in our empirical models to calculate correlations. Furthermore, we split the data into several sub-samples in order to analyse the effects of the Russian crisis, the dot-com and 9/11 shocks, the subprime mortgage crisis, and Croatia's EU accession on the dynamics and level of Croatian international financial integration. The results for the full sample point to a relatively low level of international financial integration. The degree of integration is lowest with the US and UK markets and highest with the nearby Polish and other EU markets. This might point to a certain degree of market segmentation and implies differential shock transmission from global and EU financial markets on Croatian market.

The results show that the Russian crisis, even though regional in its origin, caused the Croatian market to disintegrate relatively equally from global and regional financial markets. We did not find strong immediate effects of the dot-com and 9/11 shocks on Croatian international financial integration. However, there is some evidence that these incidents made Croatia more integrated into the global financial system, as its correlations with all markets somewhat converged in the post-crisis period. The subprime mortgage crisis had a profound effect on Croatian market integration when correlation coefficients spiked to their historically highest levels. Finally, Croatia's EU accession increased financial integration levels, but we see the main effect as a further convergence in correlation coefficients for all markets in the post-announcement period, which made Croatian financial integration less segmented.

\section{Disclosure statement}

No potential conflict of interest was reported by the authors. 
APPENDIX

\section{RUSSIAN CRISIS}

\section{TABLe 4B}

Selected univariate GARCH models and parameter estimation results for the pre-Russian crisis period

\begin{tabular}{|c|c|c|c|c|c|c|c|}
\hline Index & Model & $\omega$ & $\alpha$ & $\gamma$ & $\beta$ & $\log l$ & AIC \\
\hline CROBEX & sGARCH & $\begin{array}{c}1.587 \\
(0.002)\end{array}$ & $\begin{array}{c}0.384 \\
(0.005)\end{array}$ & & $\begin{array}{c}0.558 \\
(0.000)\end{array}$ & -501.785 & 5.007 \\
\hline S\&P500 & sGARCH & $\begin{array}{c}0.067 \\
(0.206)\end{array}$ & $\begin{array}{c}0.145 \\
(0.018)\end{array}$ & & $\begin{array}{c}0.830 \\
(0.000)\end{array}$ & -319.208 & 3.201 \\
\hline FTSE100 & sGARCH & $\begin{array}{c}0.042 \\
(0.299)\end{array}$ & $\begin{array}{c}0.132 \\
(0.021)\end{array}$ & & $\begin{array}{c}0.853 \\
(0.000)\end{array}$ & -306.173 & 3.071 \\
\hline STOXX600 & eGARCH & $\begin{array}{c}0.058 \\
(0.099)\end{array}$ & $\begin{array}{l}-0.279 \\
(0.000)\end{array}$ & $\begin{array}{c}0.132 \\
(0.201)\end{array}$ & $\begin{array}{c}0.874 \\
(0.000)\end{array}$ & -329.931 & 3.316 \\
\hline ATX & sGARCH & $\begin{array}{c}0.354 \\
(0.028)\end{array}$ & $\begin{array}{c}0.438 \\
(0.001)\end{array}$ & & $\begin{array}{c}0.560 \\
(0.000)\end{array}$ & -380.268 & 3.804 \\
\hline DAX & sGARCH & $\begin{array}{c}0.226 \\
(0.145)\end{array}$ & $\begin{array}{c}0.308 \\
(0.000)\end{array}$ & & $\begin{array}{c}0.690 \\
(0.000)\end{array}$ & -398.881 & 3.989 \\
\hline BUX & sGARCH & $\begin{array}{c}0.212 \\
(0.036)\end{array}$ & $\begin{array}{c}0.288 \\
(0.000)\end{array}$ & & $\begin{array}{c}0.570 \\
(0.000)\end{array}$ & -377.662 & 4.158 \\
\hline PX & sGARCH & $\begin{array}{l}0.07188 \\
(0.315)\end{array}$ & $\begin{array}{c}0.160 \\
(0.025)\end{array}$ & & $\begin{array}{c}0.668 \\
(0.000)\end{array}$ & -335.377 & 3.321 \\
\hline WIG20 & eGARCH & $\begin{array}{c}0.446 \\
(0.000)\end{array}$ & $\begin{array}{l}-0.368 \\
(0.000)\end{array}$ & $\begin{array}{c}0.546 \\
(0.000)\end{array}$ & $\begin{array}{c}0.822 \\
(0.000)\end{array}$ & -506.267 & 5.062 \\
\hline
\end{tabular}

\section{Table 4C}

Selected bivariate asymmetric/dynamic conditional correlation models and parameter estimation results for the pre-Russian crisis period

\begin{tabular}{|c|c|c|c|c|c|c|}
\hline Index pairs & Model & $\alpha$ & $\beta$ & $\gamma$ & $\log l$ & AIC \\
\hline CROBEX - S\&P500 & DCC & $\begin{array}{c}0.000 \\
(0.998)\end{array}$ & $\begin{array}{c}0.979 \\
(0.000)\end{array}$ & & -814.818 & 8.176 \\
\hline CROBEX - FTSE100 & DCC & $\begin{array}{c}0.004 \\
(0.764)\end{array}$ & $\begin{array}{c}0.983 \\
(0.000)\end{array}$ & & -796.573 & 7.995 \\
\hline CROBEX - STOXX600 & $\mathrm{aDCC}$ & $\begin{array}{c}0.033 \\
(0.589) \\
\end{array}$ & $\begin{array}{c}0.497 \\
(0.061)\end{array}$ & $\begin{array}{c}0.140 \\
(0.405) \\
\end{array}$ & -814.322 & 8.181 \\
\hline CROBEX - ATX & DCC & $\begin{array}{c}0.106 \\
(0.046)\end{array}$ & $\begin{array}{c}0.639 \\
(0.000)\end{array}$ & & -850.348 & 8.528 \\
\hline CROBEX - DAX & DCC & $\begin{array}{c}0.077 \\
(0.089)\end{array}$ & $\begin{array}{c}0.708 \\
(0.000)\end{array}$ & & -873.038 & 8.752 \\
\hline CROBEX - BUX & DCC & $\begin{array}{c}0.075 \\
(0.054) \\
\end{array}$ & $\begin{array}{c}0.608 \\
(0.000)\end{array}$ & & -863.490 & 8.433 \\
\hline CROBEX - PX & DCC & $\begin{array}{c}0.000 \\
(0.887) \\
\end{array}$ & $\begin{array}{c}0.946 \\
(0.000) \\
\end{array}$ & & -804.113 & 8.256 \\
\hline CROBEX - WIG20 & DCC & $\begin{array}{c}0.1062 \\
(0.014)\end{array}$ & $\begin{array}{c}0.598 \\
(0.000)\end{array}$ & & -976.138 & 9.773 \\
\hline
\end{tabular}


TABLE 4D

Selected univariate GARCH models and parameter estimation results for the post-Russian crisis period

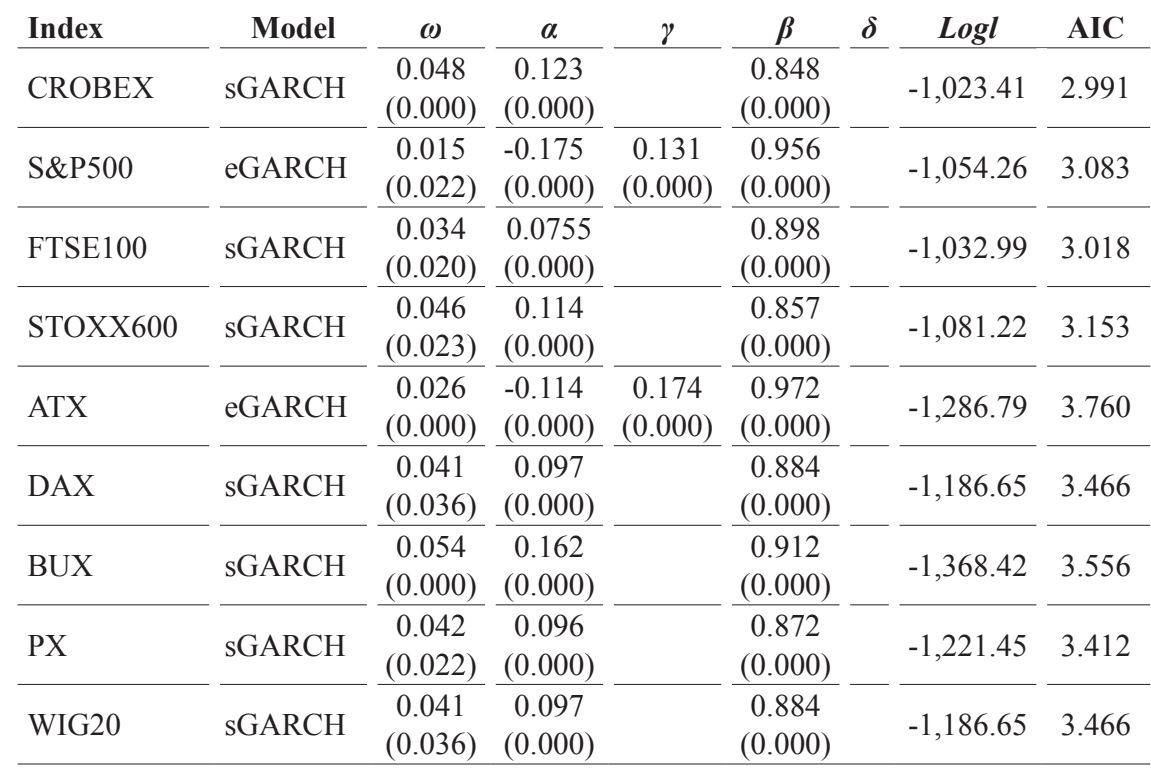

\section{TABLE 4E}

Selected bivariate models and parameter estimation results for the post-Russian crisis period

\begin{tabular}{|c|c|c|c|c|c|c|}
\hline Index pairs & Model & $\alpha$ & $\beta$ & $\gamma$ & Logl & AIC \\
\hline CROBEX - S\&P500 & DCC & $\begin{array}{c}0.012 \\
(0.381)\end{array}$ & $\begin{array}{c}0.961 \\
(0.000)\end{array}$ & & $-1,249.83$ & 8.160 \\
\hline CROBEX - FTSE100 & DCC & $\begin{array}{c}0.049 \\
(0.015)\end{array}$ & $\begin{array}{c}0.931 \\
(0.000) \\
\end{array}$ & & $-1,188.46$ & 7.763 \\
\hline CROBEX - STOXX600 & $\mathrm{DCC}$ & $\begin{array}{c}0.048 \\
(0.057)\end{array}$ & $\begin{array}{c}0.938 \\
(0.000)\end{array}$ & & $-1,237.20$ & 8.079 \\
\hline CROBEX - ATX & $\mathrm{DCC}$ & $\begin{array}{c}0.008 \\
(0.358)\end{array}$ & $\begin{array}{c}0.962 \\
(0.000)\end{array}$ & & $-1,232.79$ & 8.050 \\
\hline CROBEX - DAX & $\mathrm{aDCC}$ & $\begin{array}{c}0.041 \\
(0.057)\end{array}$ & $\begin{array}{c}0.928 \\
(0.000)\end{array}$ & $\begin{array}{c}0.019 \\
(0.685)\end{array}$ & $-1,313.21$ & 8.577 \\
\hline CROBEX - BUX & DCC & $\begin{array}{c}0.000 \\
(0.288)\end{array}$ & $\begin{array}{c}0.954 \\
(0.000) \\
\end{array}$ & & $-1,411.32$ & 8.336 \\
\hline CROBEX - PX & $\mathrm{aDCC}$ & $\begin{array}{c}0.043 \\
(0.000)\end{array}$ & $\begin{array}{c}0.956 \\
(0.000) \\
\end{array}$ & $\begin{array}{c}0.022 \\
(0.225)\end{array}$ & $-1,397.34$ & 8.621 \\
\hline CROBEX - WIG20 & DCC & $\begin{array}{c}0.094 \\
(0.126)\end{array}$ & $\begin{array}{c}0.360 \\
(0.433)\end{array}$ & & $-1,372.82$ & 8.956 \\
\hline
\end{tabular}




\section{TABLE 5B}

Selected univariate GARCH models and parameter estimation results for the pre-dot-com and $9 / 11$ period

\begin{tabular}{|c|c|c|c|c|c|c|c|}
\hline Index & Model & $\omega$ & $\alpha$ & $\gamma$ & $\beta$ & Logl & AIC \\
\hline CROBEX & sGARCH & $\begin{array}{c}1.269 \\
(0.026)\end{array}$ & $\begin{array}{c}0.221 \\
(0.000)\end{array}$ & & $\begin{array}{c}0.518 \\
(0.000)\end{array}$ & -857.067 & 4.337 \\
\hline S\&P500 & eGARCH & $\begin{array}{c}0.049 \\
(0.075)\end{array}$ & $\begin{array}{l}-0.195 \\
(0.000)\end{array}$ & $\begin{array}{c}0.027 \\
(0.472)\end{array}$ & $\begin{array}{c}0.890 \\
(0.000)\end{array}$ & -647.875 & 3.289 \\
\hline FTSE100 & sGARCH & $\begin{array}{c}0.039 \\
(0.241)\end{array}$ & $\begin{array}{c}0.023 \\
(0.148)\end{array}$ & & $\begin{array}{c}0.935 \\
(0.000)\end{array}$ & -565.582 & 2.869 \\
\hline STOXX600 & sGARCH & $\begin{array}{c}0.050 \\
(0.138) \\
\end{array}$ & $\begin{array}{c}0.043 \\
(0.025) \\
\end{array}$ & & $\begin{array}{c}0.912 \\
(0.000) \\
\end{array}$ & -598.827 & 3.036 \\
\hline ATX & gjrGARCH & $\begin{array}{c}0.026 \\
(0.052)\end{array}$ & $\begin{array}{c}0.048 \\
(0.063)\end{array}$ & $\begin{array}{c}0.057 \\
(0.145)\end{array}$ & $\begin{array}{c}0.895 \\
(0.000)\end{array}$ & -553.632 & 2.814 \\
\hline DAX & sGARCH & $\begin{array}{c}0.061 \\
(0.116) \\
\end{array}$ & $\begin{array}{c}0.048 \\
(0.007)\end{array}$ & & $\begin{array}{c}0.919 \\
(0.000)\end{array}$ & -695.427 & 3.523 \\
\hline BUX & sGARCH & $\begin{array}{c}0.002 \\
(0.052)\end{array}$ & $\begin{array}{c}0.028 \\
(0.000)\end{array}$ & & $\begin{array}{c}0.955 \\
(0.000) \\
\end{array}$ & -421.736 & 2.145 \\
\hline PX & gjrGARCH & $\begin{array}{c}0.048 \\
(0.032)\end{array}$ & $\begin{array}{c}0.045 \\
(0.000) \\
\end{array}$ & $\begin{array}{l}-0.047 \\
(0.054)\end{array}$ & $\begin{array}{c}0.962 \\
(0.000) \\
\end{array}$ & -793.558 & 3.892 \\
\hline WIG20 & gjrGARCH & $\begin{array}{c}0.049 \\
(0.048)\end{array}$ & $\begin{array}{c}0.049 \\
(0.001)\end{array}$ & $\begin{array}{l}-0.032 \\
(0.119)\end{array}$ & $\begin{array}{c}0.949 \\
(0.000)\end{array}$ & -787.256 & 3.991 \\
\hline
\end{tabular}

\section{TABLE 5C}

Selected bivariate models and parameter estimation results for the pre-dot-com and $9 / 11$ period

\begin{tabular}{|c|c|c|c|c|c|c|}
\hline Index pairs & Model & $\alpha$ & $\beta$ & $\gamma$ & $\log l$ & AIC \\
\hline CROBEX - S\&P500 & DCC & $\begin{array}{c}0.000 \\
(0.998)\end{array}$ & $\begin{array}{c}0.920 \\
(0.000)\end{array}$ & & $-1,513.53$ & 7.680 \\
\hline CROBEX - FTSE100 & DCC & $\begin{array}{c}0.012 \\
(0.223)\end{array}$ & $\begin{array}{c}0.965 \\
(0.000)\end{array}$ & & -895.32 & 4.565 \\
\hline CROBEX - STOXX600 & DCC & $\begin{array}{c}0.011 \\
(0.203)\end{array}$ & $\begin{array}{c}0.946 \\
(0.000)\end{array}$ & & $-1,207.31$ & 6.137 \\
\hline CROBEX - ATX & DCC & $\begin{array}{c}0.008 \\
(0.778)\end{array}$ & $\begin{array}{c}0.800 \\
(0.000)\end{array}$ & & $-1,410.83$ & 7.173 \\
\hline CROBEX - DAX & DCC & $\begin{array}{c}0.000 \\
(0.999)\end{array}$ & $\begin{array}{c}0.870 \\
(0.000)\end{array}$ & & $-1,549.85$ & 7.873 \\
\hline CROBEX - BUX & DCC & $\begin{array}{c}0.577 \\
(0.000)\end{array}$ & $\begin{array}{c}0.375 \\
(0.000)\end{array}$ & & $-1,822.21$ & 8.923 \\
\hline CROBEX - PX & DCC & $\begin{array}{c}0.466 \\
(0.000)\end{array}$ & $\begin{array}{c}0.394 \\
(0.000)\end{array}$ & & $-1,744.37$ & 8.647 \\
\hline CROBEX - WIG20 & DCC & $\begin{array}{c}0.451 \\
(0.000)\end{array}$ & $\begin{array}{c}0.477 \\
(0.000)\end{array}$ & & $-1,632.89$ & 8.296 \\
\hline
\end{tabular}


TABLE 5D

Selected univariate GARCH models and parameter estimation results for the dot-com and 9/11 crisis period

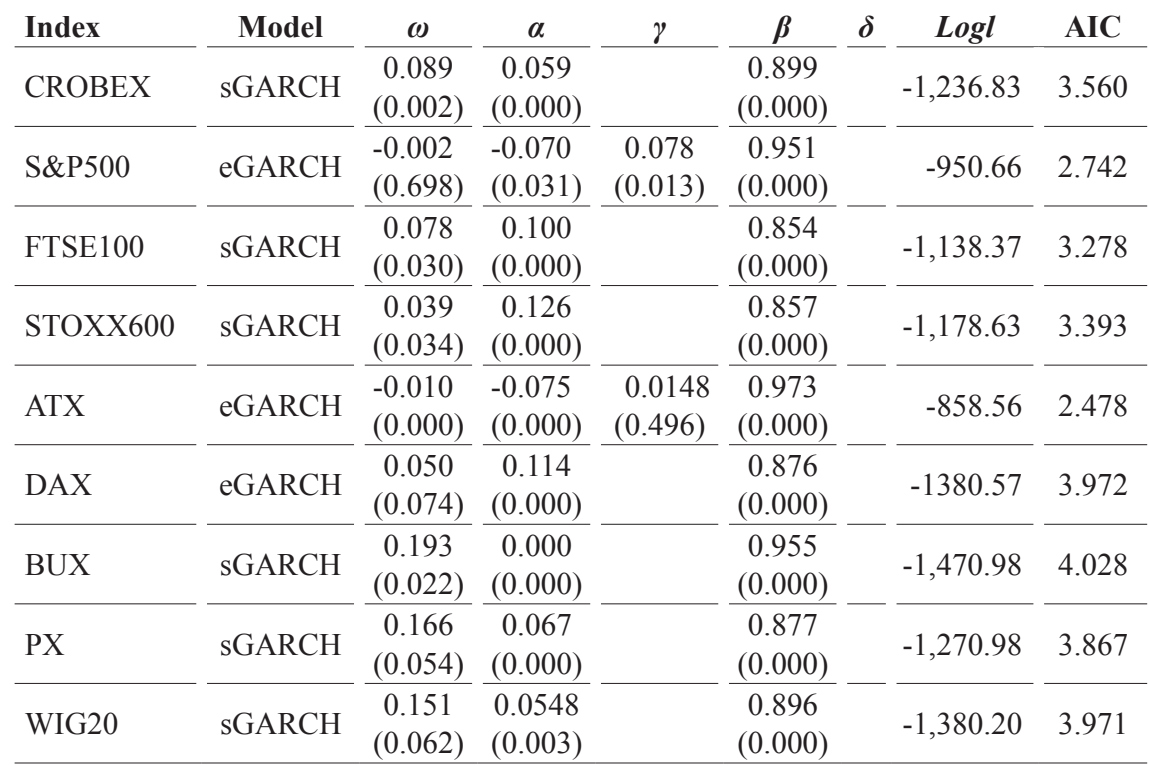

\section{TABLE 5E}

Selected bivariate models and parameter estimation results for the dot-com and 9/11 period

\begin{tabular}{|c|c|c|c|c|c|c|}
\hline Index pairs & Model & $\alpha$ & $\beta$ & $\gamma$ & $\log l$ & AIC \\
\hline CROBEX - S\&P500 & DCC & $\begin{array}{c}0.000 \\
(0.998)\end{array}$ & $\begin{array}{c}0.920 \\
(0.000)\end{array}$ & & $-1,513.53$ & 7.680 \\
\hline CROBEX - FTSE100 & DCC & $\begin{array}{c}0.012 \\
(0.223)\end{array}$ & $\begin{array}{c}0.965 \\
(0.000)\end{array}$ & & -895.32 & 4.565 \\
\hline CROBEX - STOXX600 & $\mathrm{DCC}$ & $\begin{array}{c}0.011 \\
(0.203)\end{array}$ & $\begin{array}{c}0.946 \\
(0.000)\end{array}$ & & $-1,207.31$ & 6.137 \\
\hline CROBEX - ATX & $\mathrm{DCC}$ & $\begin{array}{c}0.008 \\
(0.778)\end{array}$ & $\begin{array}{c}0.800 \\
(0.000)\end{array}$ & & $-1,410.83$ & 7.173 \\
\hline CROBEX - DAX & $\mathrm{DCC}$ & $\begin{array}{c}0.000 \\
(0.999)\end{array}$ & $\begin{array}{c}0.870 \\
(0.000)\end{array}$ & & $-1,549.85$ & 7.873 \\
\hline CROBEX - BUX & DCC & $\begin{array}{c}0.000 \\
(0.568)\end{array}$ & $\begin{array}{c}0.956 \\
(0.000) \\
\end{array}$ & & $-1,756.92$ & 8.994 \\
\hline CROBEX - PX & DCC & $\begin{array}{c}0.572 \\
(0.879)\end{array}$ & $\begin{array}{c}0.534 \\
(0.000)\end{array}$ & & $-1,589.74$ & 8.177 \\
\hline CROBEX - WIG20 & DCC & $\begin{array}{c}0.451 \\
(0.000)\end{array}$ & $\begin{array}{c}0.477 \\
(0.000)\end{array}$ & & $-1,632.89$ & 8.296 \\
\hline
\end{tabular}


TABLE 5F

Selected univariate GARCH models and parameter estimation results for the post-dot-com and $9 / 11$ period

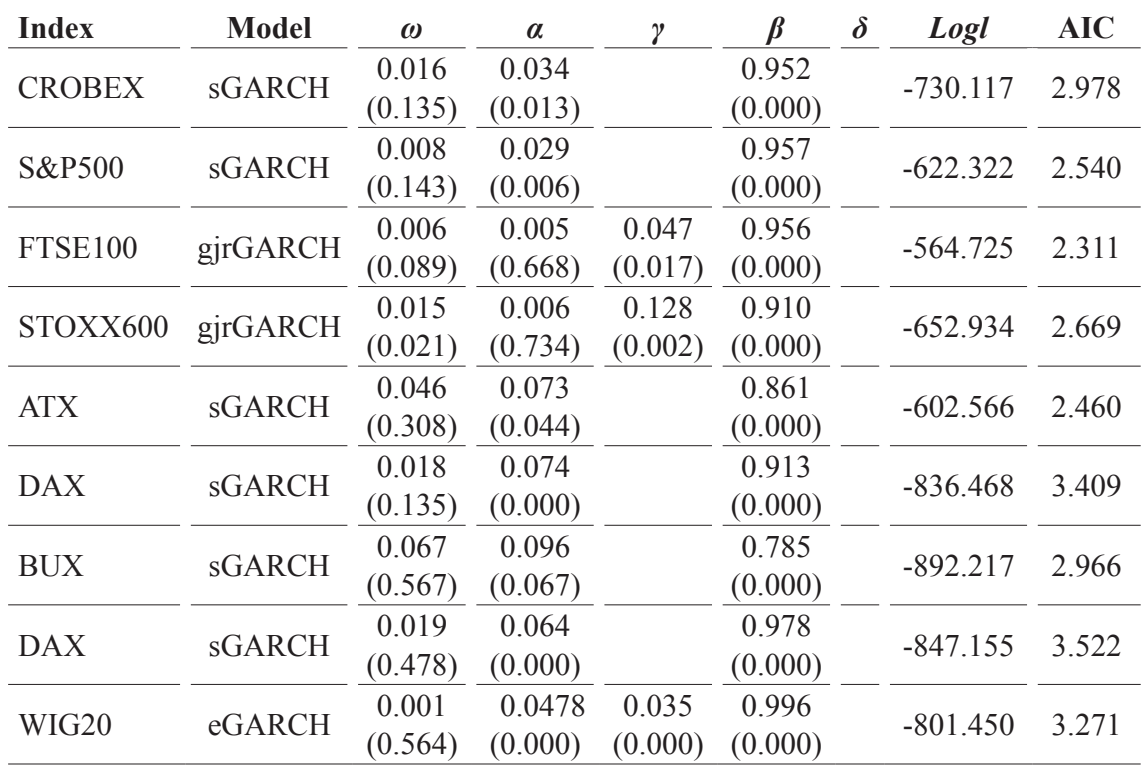

\section{TABLE 5G}

Selected bivariate models and parameter estimation results for the post-dot-com and 9/11 period

\begin{tabular}{|c|c|c|c|c|c|c|}
\hline Index pairs & Model & $\alpha$ & $\beta$ & $\gamma$ & $\log l$ & AIC \\
\hline CROBEX - S\&P500 & $\mathrm{DCC}$ & $\begin{array}{c}0.019 \\
(0.365)\end{array}$ & $\begin{array}{c}0.917 \\
(0.000)\end{array}$ & & $-1,347.70$ & 5.512 \\
\hline CROBEX - FTSE100 & $\mathrm{DCC}$ & $\begin{array}{c}0.007 \\
(0.426)\end{array}$ & $\begin{array}{c}0.980 \\
(0.000)\end{array}$ & & $-1,271.10$ & 5.209 \\
\hline CROBEX - STOXX600 & $\mathrm{DCC}$ & $\begin{array}{c}0.071 \\
(0.027)\end{array}$ & $\begin{array}{c}0.706 \\
(0.000)\end{array}$ & & $-1,379.04$ & 5.639 \\
\hline CROBEX - ATX & $\mathrm{aDCC}$ & $\begin{array}{c}0.014 \\
(0.395) \\
\end{array}$ & $\begin{array}{c}0.936 \\
(0.000)\end{array}$ & $\begin{array}{c}0.014 \\
(0.519)\end{array}$ & $-1,327.43$ & 5.433 \\
\hline CROBEX - DAX & $\mathrm{DCC}$ & $\begin{array}{c}0.019 \\
(0.073)\end{array}$ & $\begin{array}{c}0.957 \\
(0.000)\end{array}$ & & $-1,558.00$ & 6.365 \\
\hline CROBEX - BUX & DCC & $\begin{array}{c}0.027 \\
(0.008)\end{array}$ & $\begin{array}{c}0.997 \\
(0.000)\end{array}$ & & $-1,733.22$ & 6.685 \\
\hline CROBEX - PX & DCC & $\begin{array}{c}0.020 \\
(0.055)\end{array}$ & $\begin{array}{c}0.978 \\
(0.000)\end{array}$ & & $-1,655.10$ & 6.467 \\
\hline CROBEX - WIG20 & DCC & $\begin{array}{c}0.000 \\
(0.899)\end{array}$ & $\begin{array}{c}0.931 \\
(0.008)\end{array}$ & & $-1,532.08$ & 6.260 \\
\hline
\end{tabular}




\section{TABLE 6B}

Selected univariate GARCH models and parameter estimation results for the pre-subprime mortgage crisis period

\begin{tabular}{|c|c|c|c|c|c|c|c|c|}
\hline Index & Model & $\omega$ & $\alpha$ & $\gamma$ & $\beta$ & $\delta$ & $\log l$ & AIC \\
\hline CROBEX & sGARCH & $\begin{array}{c}0.272 \\
(0.000)\end{array}$ & $\begin{array}{c}0.274 \\
(0.000)\end{array}$ & & $\begin{array}{c}0.443 \\
(0.000)\end{array}$ & & -848.33 & 2.655 \\
\hline S\&P500 & sGARCH & $\begin{array}{c}0.025 \\
(0.022)\end{array}$ & $\begin{array}{c}0.053 \\
(0.000)\end{array}$ & & $\begin{array}{c}0.894 \\
(0.000)\end{array}$ & & -657.45 & 2.060 \\
\hline FTSE100 & sGARCH & $\begin{array}{c}0.015 \\
(0.040)\end{array}$ & $\begin{array}{c}0.063 \\
(0.000)\end{array}$ & & $\begin{array}{c}0.898 \\
(0.000)\end{array}$ & & -579.05 & 1.816 \\
\hline STOXX600 & gjrGARCH & $\begin{array}{c}0.038 \\
(0.000)\end{array}$ & $\begin{array}{l}-0.221 \\
(0.000)\end{array}$ & $\begin{array}{c}0.002 \\
(0.937)\end{array}$ & $\begin{array}{c}0.942 \\
(0.000)\end{array}$ & & -662.30 & 2.078 \\
\hline ATX & eGARCH & $\begin{array}{c}0.006 \\
(0.512) \\
\end{array}$ & $\begin{array}{l}-0.142 \\
(0.000)\end{array}$ & $\begin{array}{c}0.166 \\
(0.000) \\
\end{array}$ & $\begin{array}{c}0.926 \\
(0.000) \\
\end{array}$ & & -911.51 & 2.855 \\
\hline DAX & sGARCH & $\begin{array}{c}0.060 \\
(0.024) \\
\end{array}$ & $\begin{array}{c}0.101 \\
(0.001) \\
\end{array}$ & & $\begin{array}{c}0.827 \\
(0.000) \\
\end{array}$ & & -827.05 & 2.589 \\
\hline BUX & sGARCH & $\begin{array}{c}0.078 \\
(0.003) \\
\end{array}$ & $\begin{array}{c}0.458 \\
(0.000) \\
\end{array}$ & & $\begin{array}{c}0.948 \\
(0.000) \\
\end{array}$ & & $-1,452.66$ & 3.532 \\
\hline DAX & sGARCH & $\begin{array}{c}0.071 \\
(0.784)\end{array}$ & $\begin{array}{c}0.526 \\
(0.418)\end{array}$ & & $\begin{array}{c}0.921 \\
(0.000)\end{array}$ & & $-1,397.77$ & 3.459 \\
\hline WIG20 & eGARCH & $\begin{array}{c}0.009 \\
(0.015)\end{array}$ & $\begin{array}{c}0.025 \\
(0.241)\end{array}$ & $\begin{array}{c}0.116 \\
(0.050)\end{array}$ & $\begin{array}{c}0.989 \\
(0.000)\end{array}$ & & $-1,091.26$ & 3.415 \\
\hline
\end{tabular}

\section{TABLE 6C}

Selected bivariate models and parameter estimation results for the pre-subprime mortgage crisis period

\begin{tabular}{|c|c|c|c|c|c|}
\hline Index pairs & Model & $\alpha$ & $\beta$ & $\log l$ & AIC \\
\hline CROBEX - S\&P500 & DCC & $\begin{array}{c}0.0176 \\
(0.094)\end{array}$ & $\begin{array}{c}0.966 \\
(0.000)\end{array}$ & $-1,503.86$ & 4.719 \\
\hline CROBEX - FTSE100 & $\mathrm{DCC}$ & $\begin{array}{c}0.018 \\
(0.151)\end{array}$ & $\begin{array}{c}0.960 \\
(0.000)\end{array}$ & $-1,409.02$ & 4.430 \\
\hline CROBEX - STOXX600 & DCC & $\begin{array}{c}0.011 \\
(0.298)\end{array}$ & $\begin{array}{c}0.957 \\
(0.000)\end{array}$ & $-1,528.45$ & 4.795 \\
\hline CROBEX - ATX & DCC & $\begin{array}{c}0.011 \\
(0.359)\end{array}$ & $\begin{array}{c}0.961 \\
(0.000)\end{array}$ & $-1,757.78$ & 5.510 \\
\hline CROBEX - DAX & DCC & $\begin{array}{c}0.003 \\
(0.800)\end{array}$ & $\begin{array}{c}0.964 \\
(0.000)\end{array}$ & $-1,652.63$ & 5.188 \\
\hline CROBEX - BUX & DCC & $\begin{array}{c}0.019 \\
(0.667)\end{array}$ & $\begin{array}{c}0.988 \\
(0.000)\end{array}$ & $2,578.33$ & 6.366 \\
\hline CROBEX - PX & DCC & $\begin{array}{c}0.023 \\
(0.541)\end{array}$ & $\begin{array}{c}0.974 \\
(0.089)\end{array}$ & $-2,341.22$ & 6.225 \\
\hline CROBEX - WIG20 & DCC & $\begin{array}{c}0.017 \\
(0.114)\end{array}$ & $\begin{array}{c}0.955 \\
(0.000)\end{array}$ & $-1,927.81$ & 6.046 \\
\hline
\end{tabular}


TABLE 6D

Selected univariate GARCH models and parameter estimation results for the subprime mortgage crisis period

\begin{tabular}{|c|c|c|c|c|c|c|c|}
\hline Index & Model & $\omega$ & $\alpha$ & $\gamma$ & $\beta$ & $\log l$ & AIC \\
\hline CROBEX & sGARCH & $\begin{array}{c}0.188 \\
(0.018)\end{array}$ & $\begin{array}{c}0.222 \\
(0.000)\end{array}$ & & $\begin{array}{c}0.759 \\
(0.000)\end{array}$ & -838.207 & 4.128 \\
\hline S\&P500 & eGARCH & $\begin{array}{c}0.033 \\
(0.000)\end{array}$ & $\begin{array}{l}-0.171 \\
(0.000)\end{array}$ & $\begin{array}{c}0.123 \\
(0.000)\end{array}$ & $\begin{array}{c}0.976 \\
(0.000) \\
\end{array}$ & -831.024 & 4.098 \\
\hline FTSE100 & sGARCH & $\begin{array}{c}0.030 \\
(0.121)\end{array}$ & $\begin{array}{c}0.146 \\
(0.000)\end{array}$ & & $\begin{array}{c}0.852 \\
(0.000) \\
\end{array}$ & -730.960 & 3.602 \\
\hline STOXX600 & eGARCH & $\begin{array}{c}0.027 \\
(0.007)\end{array}$ & $\begin{array}{l}-0.192 \\
(0.000)\end{array}$ & $\begin{array}{c}0.075 \\
(0.059)\end{array}$ & $\begin{array}{c}0.975 \\
(0.000)\end{array}$ & -798.428 & 3.938 \\
\hline ATX & sGARCH & $\begin{array}{c}0.144 \\
(0.069)\end{array}$ & $\begin{array}{c}0.149 \\
(0.000)\end{array}$ & & $\begin{array}{c}0.835 \\
(0.000)\end{array}$ & -911.964 & 4.490 \\
\hline DAX & sGARCH & $\begin{array}{c}0.072 \\
(0.043) \\
\end{array}$ & $\begin{array}{c}0.153 \\
(0.000)\end{array}$ & & $\begin{array}{c}0.845 \\
(0.000) \\
\end{array}$ & -814.222 & 4.010 \\
\hline BUX & sGARCH & $\begin{array}{c}0.187 \\
(0.335)\end{array}$ & $\begin{array}{c}0.189 \\
(0.000)\end{array}$ & & $\begin{array}{c}0.948 \\
(0.000)\end{array}$ & -817.657 & 4.230 \\
\hline PX & sGARCH & $\begin{array}{c}0.075 \\
(0.087)\end{array}$ & $\begin{array}{c}0.112 \\
(0.000)\end{array}$ & & $\begin{array}{c}0.874 \\
(0.000)\end{array}$ & -834.447 & 4.230 \\
\hline WIG20 & sGARCH & $\begin{array}{c}0.085 \\
(0.153)\end{array}$ & $\begin{array}{r}0.0911 \\
(0.001)\end{array}$ & & $\begin{array}{c}0.896 \\
(0.000)\end{array}$ & -882.125 & 4.343 \\
\hline
\end{tabular}

\section{TABLE 6E}

Selected bivariate models and parameter estimation results for the subprime mortgage crisis period

\begin{tabular}{|c|c|c|c|c|c|c|}
\hline Index pairs & Model & $\alpha$ & $\beta$ & $\gamma$ & $\log l$ & AIC \\
\hline CROBEX - S\&P500 & DCC & $\begin{array}{c}0.026 \\
(0.109)\end{array}$ & $\begin{array}{c}0.928 \\
(0.000)\end{array}$ & & $-1,659.48$ & 8.188 \\
\hline CROBEX - FTSE100 & DCC & $\begin{array}{c}0.061 \\
(0.003)\end{array}$ & $\begin{array}{c}0.902 \\
(0.000)\end{array}$ & & $-1,511.40$ & 7.462 \\
\hline CROBEX - STOXX600 & DCC & $\begin{array}{c}0.035 \\
(0.141)\end{array}$ & $\begin{array}{c}0.915 \\
(0.000)\end{array}$ & & $-1,576.28$ & 7.780 \\
\hline CROBEX - ATX & DCC & $\begin{array}{c}0.050 \\
(0.095)\end{array}$ & $\begin{array}{c}0.804 \\
(0.000)\end{array}$ & & $-1,679.81$ & 8.288 \\
\hline CROBEX - DAX & DCC & $\begin{array}{c}0.074 \\
(0.015)\end{array}$ & $\begin{array}{c}0.819 \\
(0.000)\end{array}$ & & $-1,575.50$ & 7.777 \\
\hline CROBEX - BUX & DCC & $\begin{array}{c}0.043 \\
(0.062)\end{array}$ & $\begin{array}{c}0.865 \\
(0.000)\end{array}$ & & $-1,593.23$ & 7.922 \\
\hline CROBEX - PX & DCC & $\begin{array}{c}0.049 \\
(0.326)\end{array}$ & $\begin{array}{c}0.905 \\
(0.000)\end{array}$ & & $-1,578.13$ & 8.102 \\
\hline CROBEX - WIG20 & DCC & $\begin{array}{c}0.002 \\
(0.749)\end{array}$ & $\begin{array}{c}0.979 \\
(0.000)\end{array}$ & & $-1,664.30$ & 8.212 \\
\hline
\end{tabular}


TABLE 6F

Selected univariate GARCH models and parameter estimation results for the post-subprime mortgage crisis period

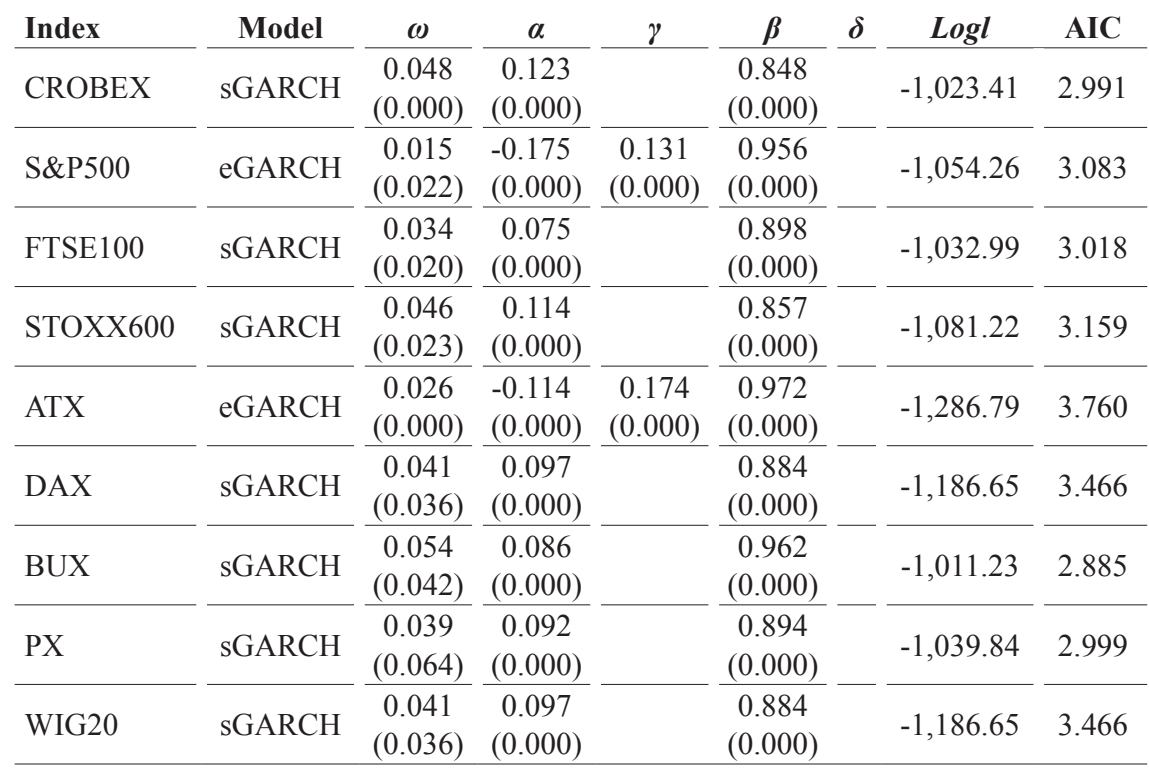

\section{TABLE 6G}

Selected bivariate models and parameter estimation results for the post-subprime mortgage crisis period

\begin{tabular}{|c|c|c|c|c|c|c|}
\hline Index pairs & Model & $\alpha$ & $\beta$ & $\gamma$ & $\log l$ & AIC \\
\hline CROBEX - S\&P500 & $\mathrm{DCC}$ & $\begin{array}{c}0.000 \\
(0.999)\end{array}$ & $\begin{array}{c}0.914 \\
(0.000)\end{array}$ & & $-2,066.35$ & 6.047 \\
\hline CROBEX - FTSE100 & $\mathrm{DCC}$ & $\begin{array}{c}0.036 \\
(0.158)\end{array}$ & $\begin{array}{c}0.785 \\
(0.000)\end{array}$ & & $-2,003.32$ & 5.864 \\
\hline CROBEX - STOXX600 & DCC & $\begin{array}{c}0.037 \\
(0.140)\end{array}$ & $\begin{array}{c}0.855 \\
(0.000)\end{array}$ & & $-2,042.42$ & 5.977 \\
\hline CROBEX - ATX & $\mathrm{aDCC}$ & $\begin{array}{c}0.051 \\
(0.009)\end{array}$ & $\begin{array}{c}0.908 \\
(0.000)\end{array}$ & $\begin{array}{c}0.014 \\
(0.700)\end{array}$ & $-2,252.50$ & 6.592 \\
\hline CROBEX - DAX & $\mathrm{aDCC}$ & $\begin{array}{c}0.036 \\
(0.524)\end{array}$ & $\begin{array}{c}0.729 \\
(0.000)\end{array}$ & $\begin{array}{c}0.055 \\
(0.644)\end{array}$ & $-2,158.95$ & 6.320 \\
\hline CROBEX - BUX & $\mathrm{DCC}$ & $\begin{array}{c}0.026 \\
(0.189)\end{array}$ & $\begin{array}{c}0.966 \\
(0.000)\end{array}$ & & $-2,047.59$ & 6.00 \\
\hline CROBEX - PX & DCC & $\begin{array}{c}0.037 \\
(0.136) \\
\end{array}$ & $\begin{array}{c}0.845 \\
(0.000)\end{array}$ & & $-2,018.22$ & 5.912 \\
\hline CROBEX - WIG20 & DCC & $\begin{array}{c}0.064 \\
(0.244)\end{array}$ & $\begin{array}{c}0.758 \\
(0.003)\end{array}$ & & $-2,185.96$ & 6.401 \\
\hline
\end{tabular}




\section{TABLE 7B}

Selected univariate GARCH models and parameter estimation results for the announcement period

\begin{tabular}{|c|c|c|c|c|c|c|c|}
\hline Index & Model & $\omega$ & $\alpha$ & $\gamma$ & $\beta$ & Logl & AIC \\
\hline CROBEX & sGARCH & $\begin{array}{c}0.017 \\
(0.038)\end{array}$ & $\begin{array}{c}0.058 \\
(0.002)\end{array}$ & & $\begin{array}{c}0.909 \\
(0.000)\end{array}$ & -577.732 & 2.331 \\
\hline S\&P500 & sGARCH & $\begin{array}{c}0.045 \\
(0.008)\end{array}$ & $\begin{array}{c}0.137 \\
(0.000)\end{array}$ & & $\begin{array}{c}0.824 \\
(0.000)\end{array}$ & -696.614 & 2.808 \\
\hline FTSE100 & eGARCH & $\begin{array}{l}-0.001 \\
(0.766) \\
\end{array}$ & $\begin{array}{l}-0.138 \\
(0.000)\end{array}$ & $\begin{array}{c}0.065 \\
(0.078) \\
\end{array}$ & $\begin{array}{c}0.981 \\
(0.000) \\
\end{array}$ & -662.568 & 2.675 \\
\hline STOXX600 & eGARCH & $\begin{array}{c}0.002 \\
(0.610)\end{array}$ & $\begin{array}{l}-0.160 \\
(0.000)\end{array}$ & $\begin{array}{c}0.041 \\
(0.000)\end{array}$ & $\begin{array}{c}0.980 \\
(0.000)\end{array}$ & -726.550 & 2.932 \\
\hline ATX & sGARCH & $\begin{array}{c}0.019 \\
(0.112) \\
\end{array}$ & $\begin{array}{c}0.047 \\
(0.001) \\
\end{array}$ & & $\begin{array}{c}0.943 \\
(0.000) \\
\end{array}$ & -916.754 & 3.690 \\
\hline DAX & sGARCH & $\begin{array}{c}0.031 \\
(0.081) \\
\end{array}$ & $\begin{array}{c}0.072 \\
(0.001)\end{array}$ & & $\begin{array}{c}0.913 \\
(0.000) \\
\end{array}$ & -867.097 & 3.491 \\
\hline BUX & sGARCH & $\begin{array}{c}0.006 \\
(0.459) \\
\end{array}$ & $\begin{array}{c}0.084 \\
(0.000) \\
\end{array}$ & & $\begin{array}{c}0.921 \\
(0.000) \\
\end{array}$ & -798.514 & 3.124 \\
\hline PX & sGARCH & $\begin{array}{c}0.031 \\
(0.985) \\
\end{array}$ & $\begin{array}{c}0.051 \\
(0.000) \\
\end{array}$ & & $\begin{array}{c}0.962 \\
(0.000) \\
\end{array}$ & -801.044 & 3.266 \\
\hline WIG20 & sGARCH & $\begin{array}{c}0.018 \\
(0.096)\end{array}$ & $\begin{array}{c}0.066 \\
(0.000)\end{array}$ & & $\begin{array}{c}0.924 \\
(0.000)\end{array}$ & -807.977 & 3.254 \\
\hline
\end{tabular}

TABLE 7C

Selected bivariate models and parameter estimation results for the announcement period

\begin{tabular}{|c|c|c|c|c|c|c|}
\hline Index pairs & Model & $\alpha$ & $\beta$ & $\gamma$ & $\log l$ & AIC \\
\hline CROBEX - S\&P500 & DCC & $\begin{array}{c}0.064 \\
(0.244)\end{array}$ & $\begin{array}{c}0.758 \\
(0.003)\end{array}$ & & $-2,185.96$ & 6.401 \\
\hline CROBEX - FTSE100 & DCC & $\begin{array}{c}0.012 \\
(0.068)\end{array}$ & $\begin{array}{c}0.982 \\
(0.000)\end{array}$ & & $-1,233.24$ & 4.986 \\
\hline CROBEX - STOXX600 & DCC & $\begin{array}{c}0.010 \\
(0.122)\end{array}$ & $\begin{array}{c}0.985 \\
(0.000)\end{array}$ & & $-1,298.36$ & 5.248 \\
\hline CROBEX - ATX & DCC & $\begin{array}{c}0.017 \\
(0.090)\end{array}$ & $\begin{array}{c}0.978 \\
(0.000)\end{array}$ & & $-1,456.72$ & 5.882 \\
\hline CROBEX - DAX & DCC & $\begin{array}{c}0.011 \\
(0.057)\end{array}$ & $\begin{array}{c}0.984 \\
(0.000)\end{array}$ & & $-1,416.62$ & 5.721 \\
\hline CROBEX - BUX & DCC & $\begin{array}{c}0.052 \\
(0.325)\end{array}$ & $\begin{array}{c}0.956 \\
(0.000)\end{array}$ & & $-1,385.76$ & 5.244 \\
\hline CROBEX - PX & DCC & $\begin{array}{c}0.012 \\
(0.074)\end{array}$ & $\begin{array}{c}0.896 \\
(0.000)\end{array}$ & & $-1,399.21$ & 5.635 \\
\hline CROBEX - WIG20 & $\mathrm{aDCC}$ & $\begin{array}{c}0.015 \\
(0.055)\end{array}$ & $\begin{array}{c}0.979 \\
(0.000)\end{array}$ & $\begin{array}{c}0.001 \\
(0.921)\end{array}$ & $-1,365.01$ & 5.519 \\
\hline
\end{tabular}


TABLE 7D

Selected univariate GARCH models and parameter estimation results for the post-accession period

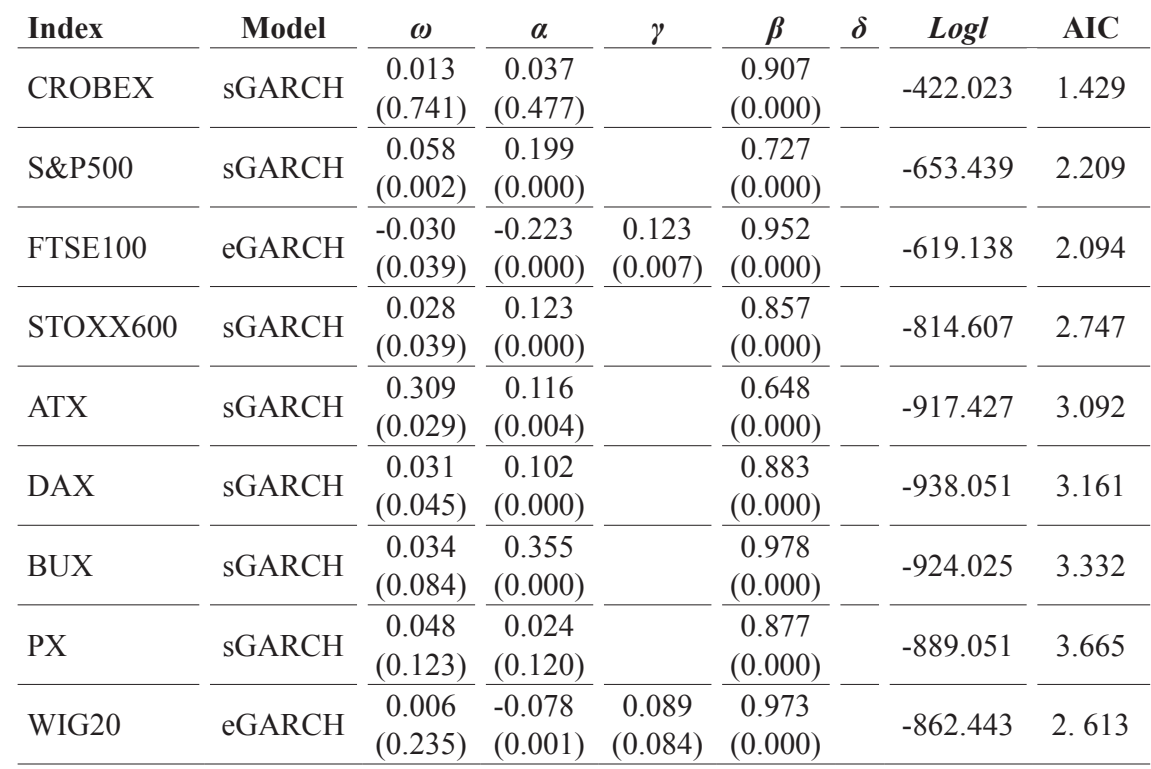

\section{TABLE 7E}

Selected bivariate models and parameter estimation results for the post-accession period

\begin{tabular}{|c|c|c|c|c|c|c|}
\hline Index pairs & Model & $\alpha$ & $\beta$ & $\gamma$ & Logl & AIC \\
\hline CROBEX - S\&P500 & DCC & $\begin{array}{c}0.000 \\
(0.997)\end{array}$ & $\begin{array}{c}0.887 \\
(0.000)\end{array}$ & & $-1,067.06$ & 3.624 \\
\hline CROBEX - FTSE100 & DCC & $\begin{array}{c}0.045 \\
(0.333)\end{array}$ & $\begin{array}{c}0.481 \\
(0.010)\end{array}$ & & $-1,030.41$ & 3.501 \\
\hline CROBEX - STOXX600 & $\mathrm{DCC}$ & $\begin{array}{c}0.037 \\
(0.357)\end{array}$ & $\begin{array}{c}0.797 \\
(0.012)\end{array}$ & & $-1,222.20$ & 4.138 \\
\hline CROBEX - ATX & $\mathrm{DCC}$ & $\begin{array}{c}0.027 \\
(0.220)\end{array}$ & $\begin{array}{c}0.836 \\
(0.000)\end{array}$ & & $-1,330.35$ & 4.501 \\
\hline CROBEX - DAX & $\mathrm{DCC}$ & $\begin{array}{c}0.027 \\
(0.140)\end{array}$ & $\begin{array}{c}0.906 \\
(0.000)\end{array}$ & & $-1,345.52$ & 4.554 \\
\hline CROBEX - BUX & $\mathrm{DCC}$ & $\begin{array}{c}0.035 \\
(0.566) \\
\end{array}$ & $\begin{array}{c}0.795 \\
(0.000)\end{array}$ & & $-1,328.64$ & 4.347 \\
\hline CROBEX - PX & $\mathrm{DCC}$ & $\begin{array}{c}0.000 \\
(0.412)\end{array}$ & $\begin{array}{c}0.741 \\
(0.000)\end{array}$ & & $-1,202.54$ & 4.255 \\
\hline CROBEX - WIG20 & DCC & $\begin{array}{c}0.000 \\
(0.998)\end{array}$ & $\begin{array}{c}0.905 \\
(0.000)\end{array}$ & & $-1,280.62$ & 4.334 \\
\hline
\end{tabular}




\section{REFERENCES}

1. Baele, L. [et al.], 2004. Measuring financial integration in the Euro area. Oxford Review of Economic Policy, 20(4), pp. 509530. doi: 10.1093/oxrep/grh030

2. Berglof, E. [et al.], 2009. Understanding the crisis in emerging Europe. European Bank for Reconstruction and Development European Central Bank Working Paper, No. 109

3. Bollerslev, T., 1986. Generalized autoregressive conditional heteroskedasticity. Journal of Econometrics, 31(3) , pp. 307-27. doi:10.1016/0304-4076(86)90063-1

4. Capiello, L., Engle, R. and Sheppard, K., 2006a. Asymmetric dynamics in the correlations of global equity and bond returns. Journal of Financial Econometrics, 4(4), pp. 537-572. doi: 10.1093/jjfinec/nb1005

5. Cappiello, L. [et al.], 2006b. Financial integration of new EU member states. European Central Bank Working Paper, No. 683.

6. Dajcman, S., 2013. Dependence between Croatian and European stock markets - A copula GARCH approach. Zbornik radova ekonomskog fakulteta $u$ Rijeci, 31(2), pp. 209232.

7. Egert, B. and Kocenda, E., 2007. Interdependence between Eastern and Western European stock markets: evidence from intraday data. Economic Systems, 31(2), pp. 184203. doi: 10.1016/j.ecosys.2006.12.004

8. Engle, R. F. and Granger, C. W. J., 1987. Co-Integration and Error Correction: Representation, Estimation, and Testing. Econometrica, 55(2), pp. 251-276 doi: 10.2307/1913236

9. Engle, R. F. and Sheppard, K., 2001. Theoretical and empirical properties of dynamic conditional correlation MVGARCH. University of California. Economic Working Paper Series 8554.

10. Engle, R. F., 1982. Autoregressive conditional heteroskedasticity with estimates of the variance of U.K. inflation. Econometrica, 50(4), pp. 987-1008. doi: $10.2307 / 1912773$

11. Forbes, K., 2004. The Asian flu and Russian virus: the international transmission of crises in firm-level data. Journal of International Economics, 63(1), pp. 59-92. doi: 10.1016/S0022-1996(03)00044-8

12. Gelos, R. G. and Sahay, R., 2000. Financial market spillovers in transition economies. IMF Working Papers, No. 00/71.

13. Gijka, D. and Horvath, R., 2012. Stock market co-movements in Central Europe: evidence from asymmetric DCC model. Working Papers Series, No. 1035.

14. Glosten, L., Jarannthan, R. and Runkle, E. D., 1993. Relationship between the expected value and volatility of the nominal excess returns on stocks. Journal of Finance, 48(5), pp. 1779-1802. doi: 10.1111/j.1540-6261.1993.tb05128.x

15. Horvath, R. and Petrovski, D. 2013. International Stock Market Integration: Central and South Eastern Europe Compared. Economic Systems 37(1), pp. 81-91. doi: 10.1016/j.ecosys.2012.07.004

16. Ivanov, M. 2014. Volatility spillovers and stock market co-movements among Western, Central and Southeast European stock markets. European Journal of Economics and Management, 1(1), pp. 47-72 
17. Jochum, C., Kirchgassner, G. and Platek, M., 1999. A long-run relationship between Eastern European stock markets? Cointegration and the 1997/98 crisis in emerging markets. Weltwirtschaftliches Archiv, 135, pp. 454-479. doi: 10.1007/BF02707335

18. Kassim, S. H., 2010. Global financial crisis and integration of Islamic stock markets in developed and developing countries. Institute of Developing Economies Japan External Trade Organization, V.R.F Series 461

19. Kenourgios, D., Samitas, A. and Paltalids, N., 2009. Financial market dynamics in an enlarged European Union. Journal of Economic Integration, 24(2), pp. 197-221. doi: https://doi.org/10.11130/jei.2009.24.2.197

20. Egert, B. and Kocenda, E., 2011. Time-varying synchronization of European stock markets. Empirical Economics, 40(2), pp. 393-407. doi: 10.1007/ s00181-010-0341-3

21. Macdonald, R., 2001. "Transformation of external shocks and capital market integration". In: M. Schröder, ed. The new capital markets in Central and Eastern Europe. Berlin: Springer Verlag, pp. 164-191.

22. Manda, K., 2010. Stock market volatility during the 2008 financial crisis. Glucksman Institute for Research in Securities Markets. Working Paper, No. 09.

23. Melitz, J. and Zumer, F. 1999. Interregional and international risk sharing and lessons for EMU. Carnegie-Rochester Conference Series on Public Policy, No. 51

24. Nelson, D., 1991. Conditional heteroskedasticity in asset returns: a new approach. Econometrica, 59(2), pp. 347-70. doi: 10.2307/2938260

25. Syriopoulos, T. and Roumpis, E., 2009. Dynamic correlations and volatility effects in the Balkan equity markets. Journal of International Financial Markets, Institutions and Money, 19 (1), pp. 565-587. doi: 10.1016/j.intfin.2008.08.002

26. Syriopoulos, T., 2004. International portfolio diversification to Central European stock markets. Applied Financial Economics, 14(17), pp. 1253-1268. doi: http://dx.doi.org/10.1080/0960310042000280465

27. Voronkova, S., 2004. Equity market integration in Central European Emerging markets: a co-integration analysis with shifting regimes. International Review of Financial Analysis, 13(5), pp. 633-647. doi: 10.1016/j.irfa.2004.02.017

28. Wang, P. and Moore, T., 2008. Stock market integration for the transition economies: time-varying conditional correlation approach. The Manchester School, 76(s1), pp. 116133. doi: 10.1111/j.1467-9957.2008.01083.x 